\title{
Sedimentary Basins of the East Siberian Sea and the Chukchi Sea and the Adjacent Area of the Amerasia Basin: Seismic Stratigraphy and Stages of Geological History
}

A. M. Nikishin ${ }^{a, *}$, K. F. Startseva ${ }^{a}$, V. E. Verzhbitsky ${ }^{b}$, S. Cloetingh ${ }^{c}$, N. A. Malyshev ${ }^{b}$, E. I. Petrov ${ }^{d}$,

\author{
H. Posamentier ${ }^{e}$, S. I. Freiman ${ }^{a}$, M. D. Lineva ${ }^{f}$, and N. N. Zhukov ${ }^{a}$ \\ ${ }^{a}$ Department of Geology, Moscow State University, Moscow, 119991 Russia \\ ${ }^{b}$ PJSC NK Rosneft, Moscow, 117997 Russia \\ ${ }^{c}$ Utrecht University, PO Box 80125, Utrecht, 3508 TC Netherlands \\ ${ }^{d}$ Ministry of Natural Resources and Environment of the Russian Federation, Moscow, 125993 Russia \\ ${ }^{e}$ Consultant, 25 Topside Row Drive, The Woodlands, TX 77380, United States \\ ${ }^{f}$ OOO Center for the Study of Geological Data (GeoGrid), Moscow, 119071 Russia \\ *e-mail:nikishin@geol.msu.ru
}

Received May 27, 2019; revised July 23, 2019; accepted September 24, 2019

\begin{abstract}
The seismic stratigraphy scheme for the shelf basins of the East Siberian Sea and the Chukchi Sea region and the adjacent deepwater area of the Amerasia basin has been developed, and mega-sequences (or tectonostratigraphic units) with the conventional ages of $125-100,100-80,80-66,66-56,46-45,45-34$, 34-20, 20-0 Ma are distinguished. Zhokhov foredeep basin of the Late Jurassic-Neocomian age is distinguished between the New Siberia and the De Long islands. Three main phases of rifting are identified on the shelves in the region with ages of 125-100, 66-56, and 45-37 Ma. The main phase of continental rifting occurred in the Podvodnikov and Toll basins at 125-100 Ma. The typical clinoform accumulation of sediments occurred at the edge of the shelf at 66-20 Ma. We identified three syntectonic epochs of the formation of clinoform sequences with the ages of 66-45, 45-34, and 34-20 Ma. The phase of uplifting and compression in the region of Wrangel Island happened at $\approx 66 \mathrm{Ma}$. The relatively monotonous tectonic setting with approximately the same thicknesses of the sedimentary cover began at $20 \mathrm{Ma}$.
\end{abstract}

Keywords: Arctic, North Chukchi Basin, East Siberian Sea Basin, Podvodnikov Basin, Mendeleev Rise, seismic stratigraphy

DOI: $10.1134 / \mathrm{S} 0016852119060104$

\section{INTRODUCTION}

The shelves of the East Siberian and Chukchi Seas, jointly with the deepwater Podvodnikov and Toll basins (Chukchi Abyssal Plain) and the Mendeleev Rise, are conventionally referred to the East Arctic of Russia and the adjacent territories (Figs. 1, 2). In recent years, many seismic profiles (Fig. 1) that make it possible to significantly refine the geological structure of the huge area have been made for this region.

Geographically, the territory covers the dryland of the northern part of Siberia, Chukotka, and Alaska, New Siberian Islands, and Wrangel Island. The continental slope region is located to the north. The large geomorphological structure of the continental slope is the Kucherov terrace. In the deepwater part are two large basins: Podvodnikov and Toll, which are separated by the Mendeleev Rise. Towards the west from the Podvodnikov basin is Lomonosov Ridge, which separates the Amerasian and Eurasian deepwater basins. The Chukchi Plateau lies to the east of the Toll Basin.

The dryland and the islands are dominated by the Verkhoyansk-Chukotka folded regions and the orogenic events were completed before the Aptian (Early Cretaceous) [1, 10, 13, 16, 50, 53, 58]. Large sedimentary troughs are distinguished on the shelf [7, 24, 48, 52, 53]. North Chukchi (to the north of Wrangel Island), South Chukchi (to the south of Wrangel Island), the East Siberian Sea basin in the eponymous sea (Melville, North-Melville, and Manskii troughs), Anisin trough (to the north of the North Siberian Islands).

The Zhokhov-Wrangel-Herald occurs on the thrust belt on the shelf of the sea, which is traced northward of Wrangel Island and between the New Siberian Islands and the De Long Islands [8, 10, 24]. The Mesozoic (Pre-Aptian) Chukotka-Novosibirsk orogen extends southward of this belt. To the north is a large block with the pre-Mesozoic continental crust, 


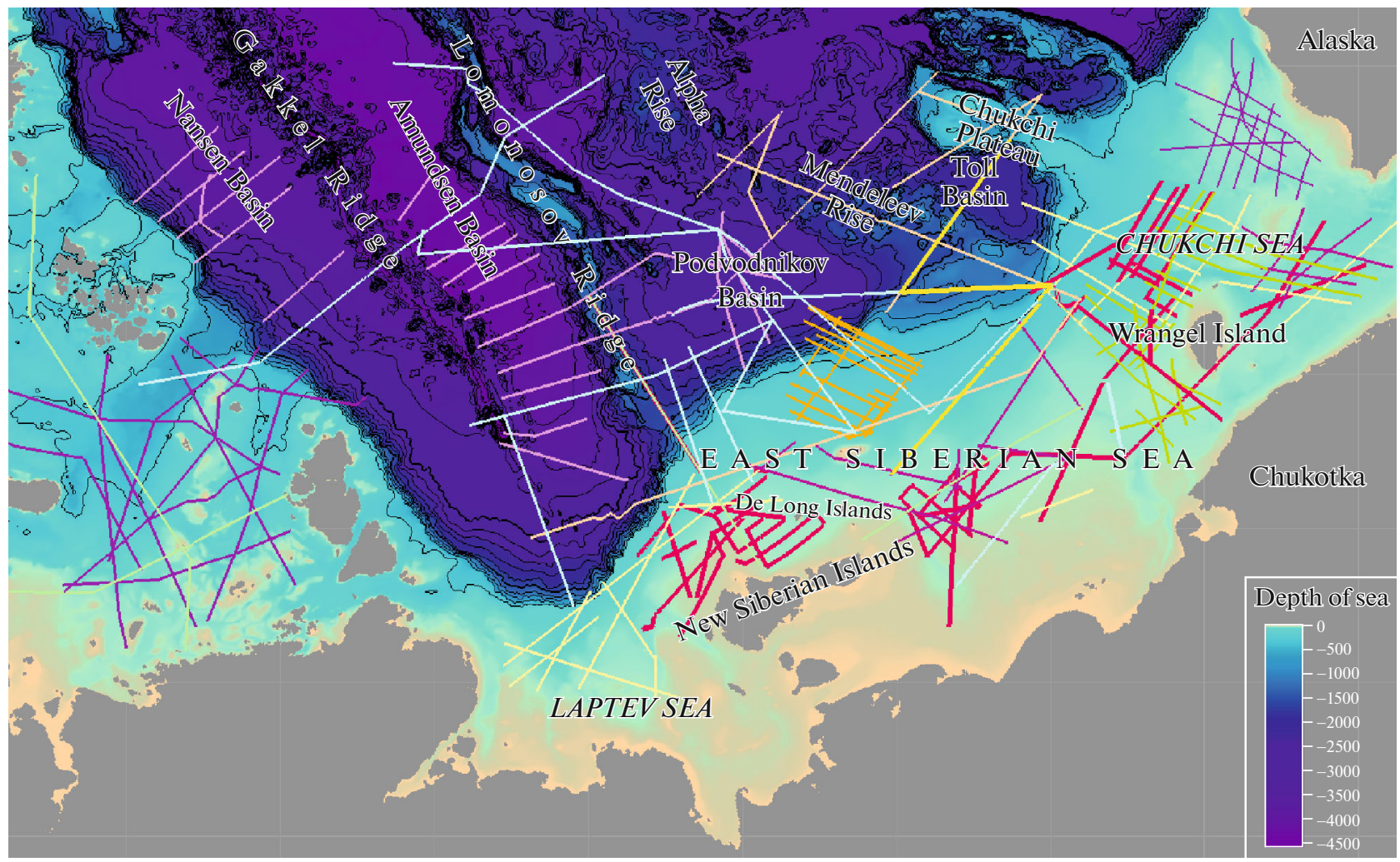

Fig. 1. A bathymetric map of the Eastern Arctic. The location of seismic profiles is shown (lines).

which N.S. Shatskii named the Hyperborean platform [13] and L.P. Zonenshain called Arctida [2, 40, 65]. The fragments of this large superterrain are the De Long massif in the area of the De Long Islands and the block of the Chukchi Plateau [10, 24].

The deepwater part of the Arctic Ocean includes the Lomonosov Ridge and the Chukchi Plateau. All researchers believe that these terrains have a continental crust $[51,53]$. For the Podvodnikov and Toll basins different points of view exist. Some researchers consider that they are underlain by Mesozoic oceanic crust, others assume that the basins lie on continental crust that is strongly thinned by rifting [34, 35, 46, 49 , $51,53,54]$.

It is generally accepted that the Mendeleev Rise is a Mesozoic volcanic structure, while the opinion exists that it is an oceanic plateau with basaltic crust [35]; however, researchers admit that the basement is a strongly thinned continental crust [2, 18, 36, 46, 49, 53, 57].

Many geological problems in the East Arctic. An important problem is substantiating the common stratigraphic scheme for this region. Many new regional seismic profiles have been made in recent years. Based on these data, many Russian organizations developed the seismic stratigraphic schemes for the Arctic region. The main studies include the works performed at the Karpinsky All-Russian Geological Research Institute (St. Petersburg, Russia) [23, 53],
OAO Dal'morneftegeofizika (Yuzhno-Sakhalinsk, Russia) [7], OAO MAGE (Murmansk, Russia) [4, 5], VNIIO (St. Petersburg, Russia) [9, 54], Moscow State University, Department of Geology (Moscow, Russia) [46, 49, 47, 61] Rosneft Oil Company and by the researchers from the European countries and the United States [21, 26, 29-32, 38, 45, 63].

The purpose of this work is to refine and supplement the regional seismic stratigraphy based on the interpretation of the most seismic data.

\section{METHODS OF STUDY}

The initial data are the network of regional seismic profiles (Fig. 1). All of these profiles form a single computer project in the Petrel computer system, which allows the creation of composite seismic profiles and tracing all boundaries in the system of all profiles. There are no boreholes in the region; therefore, the only method for the development of seismic stratigraphy is distinguishing seismic-stratigraphic megacomplexes (mega-sequences), i.e., identifying tectonostratigraphic units by the procedure in [48]. In the system of tectonostratigraphy, the seismic profiles are interpreted in terms of tectonic settings of the formation of different seismostratigraphic megacomplexes, that is, syn-rift, post-rift complexes, syn-inversion complexes, complexes of foredeeps, etc. are distinguished. 


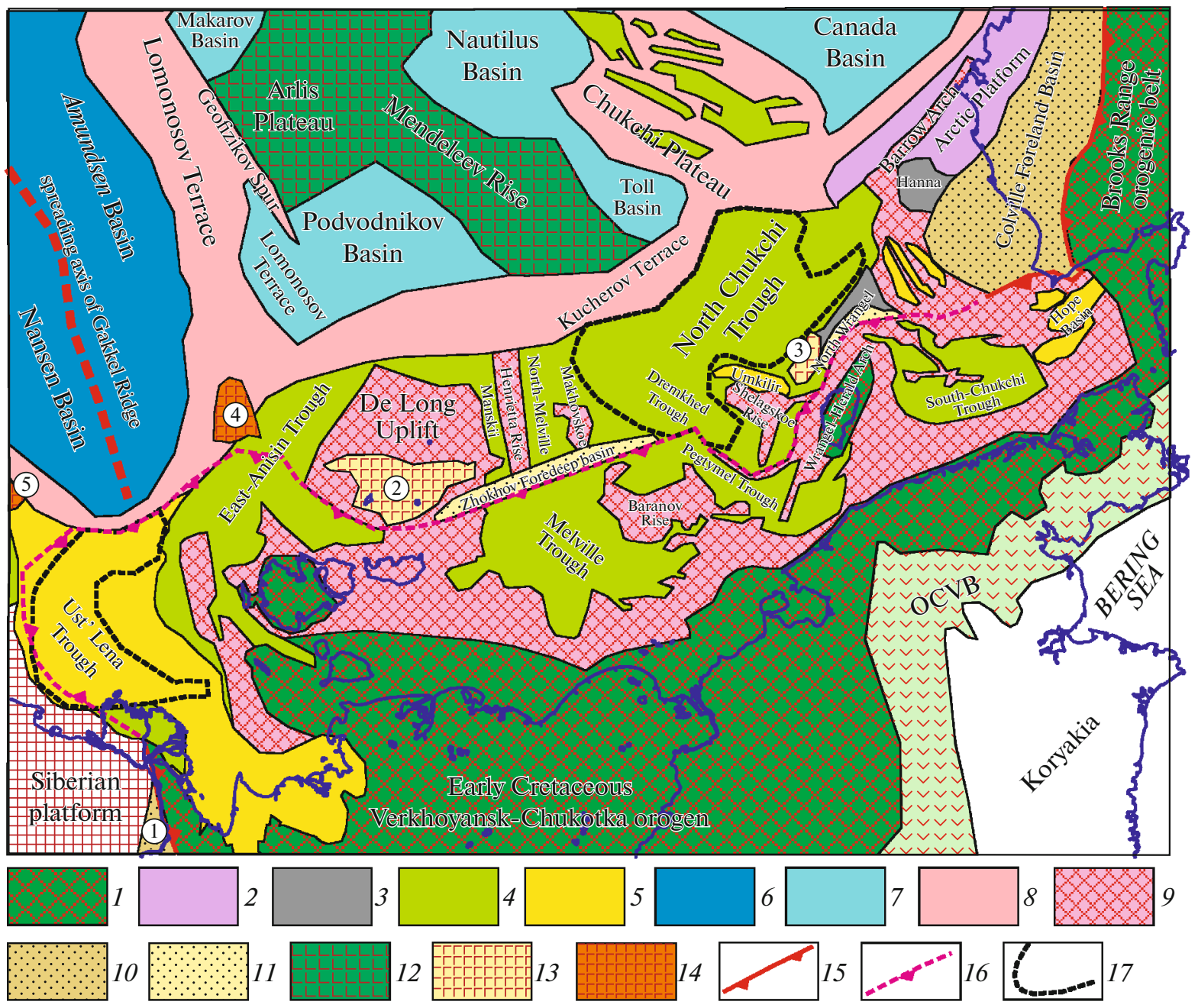

Fig. 2. A tectonic scheme of the East Arctic area (according to [46, 49], amended and revised). Designations (numbers in circles): 1, Pre-Verkhoyansk foredeep; 2, De-Long traps; 3, North-Chukchi traps; 4, Anisin-Lomonosov traps; 5, Faddei traps. OCVB, Cretaceous Okhotsk-Chukotka volcanic belt. Arbitrary notes: (1) Cretaceous orogens; (2) poorly defined sedimentary basins; (3-5) sedimentary basins with rifting: (3) Carboniferous, (4) Aptian-Albian, (5) Cenozoic; (6) Eurasian basin with oceanic crust; (7) basins with hyper-extended continental crust; (8) passive continental margins and continental terraces; (9) relative rises overlaid by a sedimentary cover; $(10,11)$ foredeeps: $(10)$ Mesozoic, $(11)$ Zhokhov Late-Jurassic Neocomian, overlain by younger sediments; (12) Cretaceous rift-volcanic structure of the Mendeleev Rise; $(13,14)$ probable traps beneath younger sediments: (13) Aptian-Albian, (14) Paleocene-Eocene; $(15,16)$ thrust belt in front of the front: (15) Mesozoides, (16) Mesozoides overlaid by younger sediments; (17) the deepest areas of sedimentary basins with strongly thinned crust.

In this work, we used the Russian federal seismic profiles primarily from the Arktika series [54], which were made for the project by the External Borders of the Arctic Shelf of Russia, as well as the federal seismic profiles made by companies such as OAO MAGE (St. Petersburg, Russia), OAO Sevmorneftegeofizika (Murmansk, Russia), OAO Dal'morneftegeofizika (Yuzhno-Sakhalinsk, Russia).

\section{SEISMIC STRATIGRAPHY SUBSTANTIATION OF THE ARCTIC REGION}

In this work, we rely on the suggested modified scheme of the Arctic region seismic stratigraphy [11,
$27,37,40,46,47,49]$. The scheme is based on the following group of data:

(1) correlation of seismic horizons with the ages of linear magnetic anomalies in the Eurasian Basin [12, 46, 47, 49];

(2) correlation of seismic horizons with the data of ACEX drilling boreholes on Lomonosov Ridge [33, 17, 60];

(3) correlation of seismic horizons with the results of lithological and faunistic sampling of three slopes in the area of the Mendeleev Rise by submersible vessels [57];

(4) correlation of seismic horizons with the data of drilling on the Alaska shelf $[42,44,56]$. 
As a result, we identified seismic boundaries with the approximate ages of $125,100,80,66,56,45,34$, and $20 \mathrm{Ma}$. Our scheme supplements to some extent one of the first seismic-stratigraphic schemes for the East Arctic developed by S.B. Sekretov [55]. Tectonically, our model is the development of one of the variants of the geological history of the Arctic, which was suggested by E. Miller and V.E. Verzhbitsky [43]:

(1) The boundary of $125 \mathrm{Ma}$ is based on the fact that in the area of the De Long Uplift, at the base of the rift basins are packages of bright reflectors that may correspond to basalts from the De Long Plateau with an isotope age in the interval of 130-110 Ma [46, 49]. This boundary corresponds to the Brookian (PreAptian) unconformity on the Alaska shelf [32].

(2) The boundary of $100 \mathrm{Ma}$ corresponds approximately to the rift-post-rift boundary in the area of the East Siberian Sea basin [46, 49]. This boundary corresponds to the Cenomanian Unconformity (CU) on the Alaska shelf [32].

(3) The boundary of 80 Ma corresponds approximately to the end of volcanism on the Mendeleev Rise.

(4) The boundary of 66 Ma corresponds to the MidBrookian Unconfirmity (MBU) boundary on the Alaska shelf. It is related to the drilling data, is observed on the seismic profiles [32, 29, 49], and corresponds approximately to the bottom of the lower clinoform sequence of the North Chukchi Basin [46, 49].

(5) The boundary of $56 \mathrm{Ma}$ corresponds to the rift-post-rift boundary in the western part of the Laptev Sea basin; this is a Breakup Unconformity boundary, which corresponds to the onset of spreading in the Eurasian Basin [27, 47].

(6) The boundary of $45 \mathrm{Ma}$ corresponds to the onset of ultra-slow spreading in the Gakkel Ridge and is clearly correlated with the ages of magnetic anomalies in the Eurasian basin [46, 47]. This boundary corresponds approximately to the Mid-Eocene unconformity (MEu) on the Alaska shelf [32] and is correlated with the bottom of the upper cliniform sequence of the North Chukchi Basin (Trough) [49]. The boundary of $45 \mathrm{Ma}$ corresponds to the age of unconformity between the Eocene and Paleozoic deposits according to the data of drilling in the Hope Basin in the American part of the South Chukchi Basin [44].

(7) The boundary of $34 \mathrm{Ma}$ is delineated by correlating seismic horizons with the ages of linear magnetic anomalies in the Eurasian Basin [46]. This boundary has not yet been sufficiently substantiated; it is likely to conform to the Top Eocene boundary (TE) $33.9 \mathrm{Ma}$, from [29]. The boundary of $34 \mathrm{Ma}$ corresponds to the unconformity between the Eocene and Oligocene deposits according to the data of drilling in the Hope Basin in the American part of the South Chukchi Basin [44].

(8) The boundary of $20 \mathrm{Ma}$ is delineated by correlating seismic horizons with ages of linear magnetic anomalies in the Eurasian Basin [46, 47]; however, its accurate position is ambiguous according to these data. The renewal of sedimentation on the Lomonosov Ridge after the discontinuity in the sedimentation process (18.2 Ma) [17, 33] and the phase of tectonic activity and erosion on the Alpha Ridge ( 14.5-22 Ma) correspond to this boundary $[19,20]$.

(9) Between 18.2 and 17.5 Ma, the water basin of the Arctic Ocean through the Fram Strait was fully connected to the North Atlantic basin; the circulation of water masses, which was common with the Atlantic, started in the Arctic Ocean [33]. Our studies show that the sediments related to the powerful general-oceanic bottom currents started to form at approximately $18 \mathrm{Ma}$ [11].

In general, our scheme of seismic stratigraphy corresponds to the scheme of seismic stratigraphy for the shelf of Alaska and North Chukchi Basin presented in [32]. The only important difference is that the American researchers assume at that work that the Upper Jurassic deposits may be found at the bottom of the section of the North Chukchi Basin below the BU horizon, (we note that the presence of Jurassic deposits in the Toll basin was also assumed in [29]). Rosneft' Company (Moscow) developed the seismic stratigraphic scheme for this region similar to ours [8].

Our seismic stratigraphic scheme significantly differs from similar schemes made by researchers from the Karpinsky Russian Geological Research Institute (St. Petersburg), OAO MAGE (Murmansk), and VNIIO (St. Petersburg) [4, 5, 23, 54]. These researchers took the correlation of seismic profiles with the boreholes on the Alaska shelf as a basis of seismic stratigraphy. As a result, they found that the lower parts in the sections of the North Chukchi, Podvodnikov, Toll, and other basins contain a thick Upper Paleozoic-Jurassic stratum of the deposits. This viewpoint has two key problems. The first problem, the correlation of seismic profiles with the distant boreholes, is ambiguous. This procedure was also carried out by researchers from the United States [32] and in Rosneft' [8]. In this case, the variants with the possible Paleozoic cover in the North Chukchi Basin failed. The second problem is that the Podvodnikov basin has a strongly thinned continental crust (some researchers assume that the crust is oceanic). In the opinion of researchers, the crust age is either Cretaceous or Jurassic. The variants when the Paleozoic horizontal cover could lie on the Mesozoic crust are excluded.

We present additional arguments for refining the seismic stratigraphy of the Arctic Ocean region. The boundaries of $125,100,80,66,56,45,34$, and $20 \mathrm{Ma}$ are not considered as accurate and isochronous, since some boundaries can be nonisochronous, this especially concerns the erosion surfaces. 

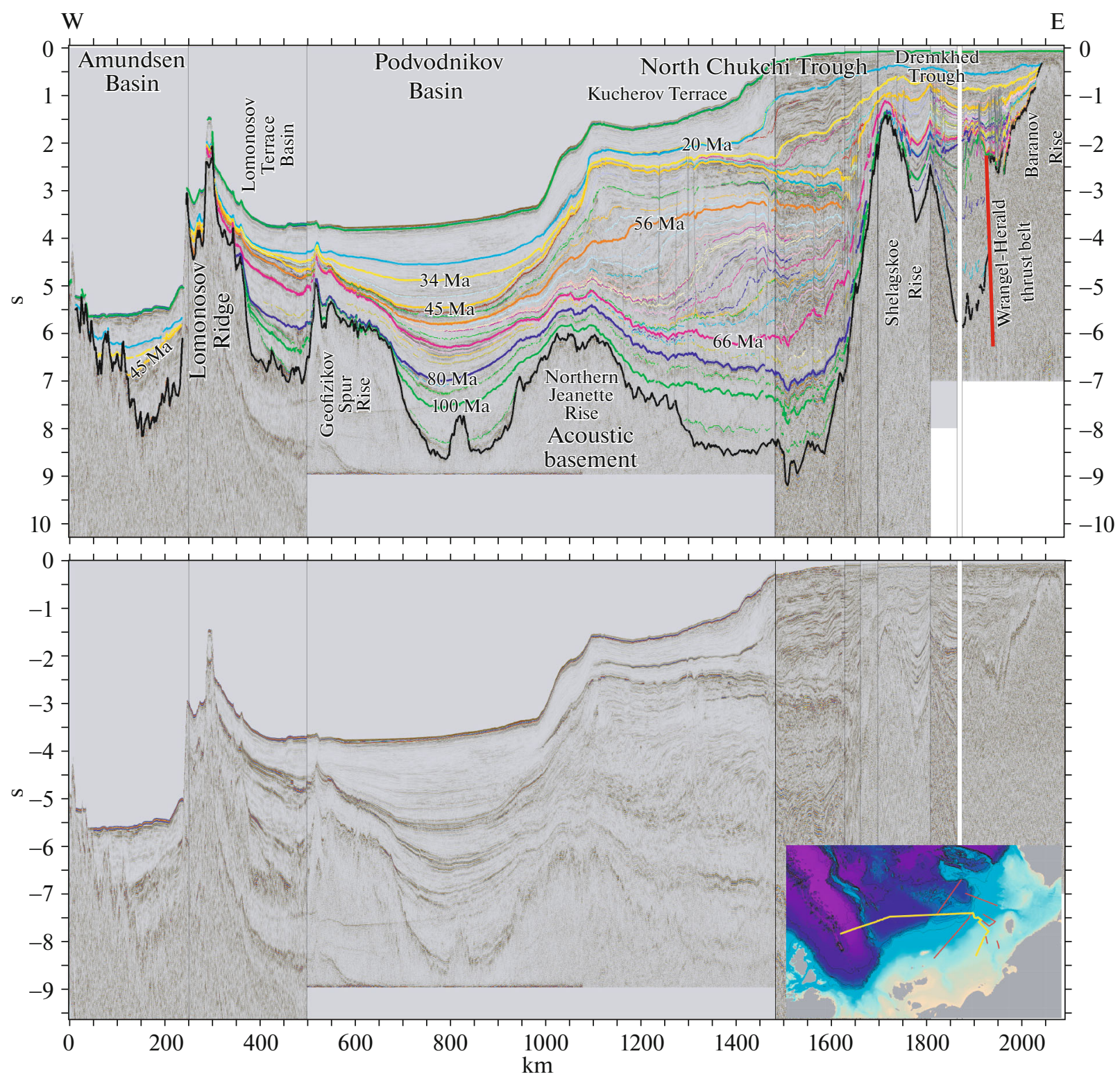

Fig. 3. The composite seismic profile-1. The shown are position of profile-1 (map in inset bottom right) and conventional geological age, Ma (numbers at boundaries). Horizontal scale is in $\mathrm{km}$; vertical scale, s (double time).

\section{INTERPRETATION OF REGIONAL SEISMIC PROFILES}

To refine the seismic stratigraphy of the Arctic we interpreted the seismic profiles (Fig. 1) based on the most informative seismic data.

\section{Composite Seismic Profile-1}

The composite seismic profile and its interpretation are shown (Fig. 3). The profile goes from the shelf of the East Siberian Sea through the North Chukchi Trough and the Podvodnikov Basin and intersects the Lomonosov Ridge. This profile is supporting for identifying the main seismic-stratigraphic units. The fol- lowing tectonostratigraphic units (seismic sequences) are naturally distinguished for this profile with conventional names:

(1) the syn-rift sequence (between the acoustic basement and the horizon of $100 \mathrm{Ma}$ ),

(2) the post-rift sequence with approximately similar thicknesses (between the horizons of 100 and $66 \mathrm{Ma}$ ),

(3) the lower clinoform syn-tectonic sequence with a sudden decrease in thicknesses towards the Podvodnikov basin and the Geofizikov Spur Rise (between the horizons of 66 and $45 \mathrm{Ma}$ ),

(4) the upper clinoform syn-tectonic sequence with a sharp decrease in thicknesses towards the Lomonosov Ridge (between horizons of 45 and $20 \mathrm{Ma}$ ), 

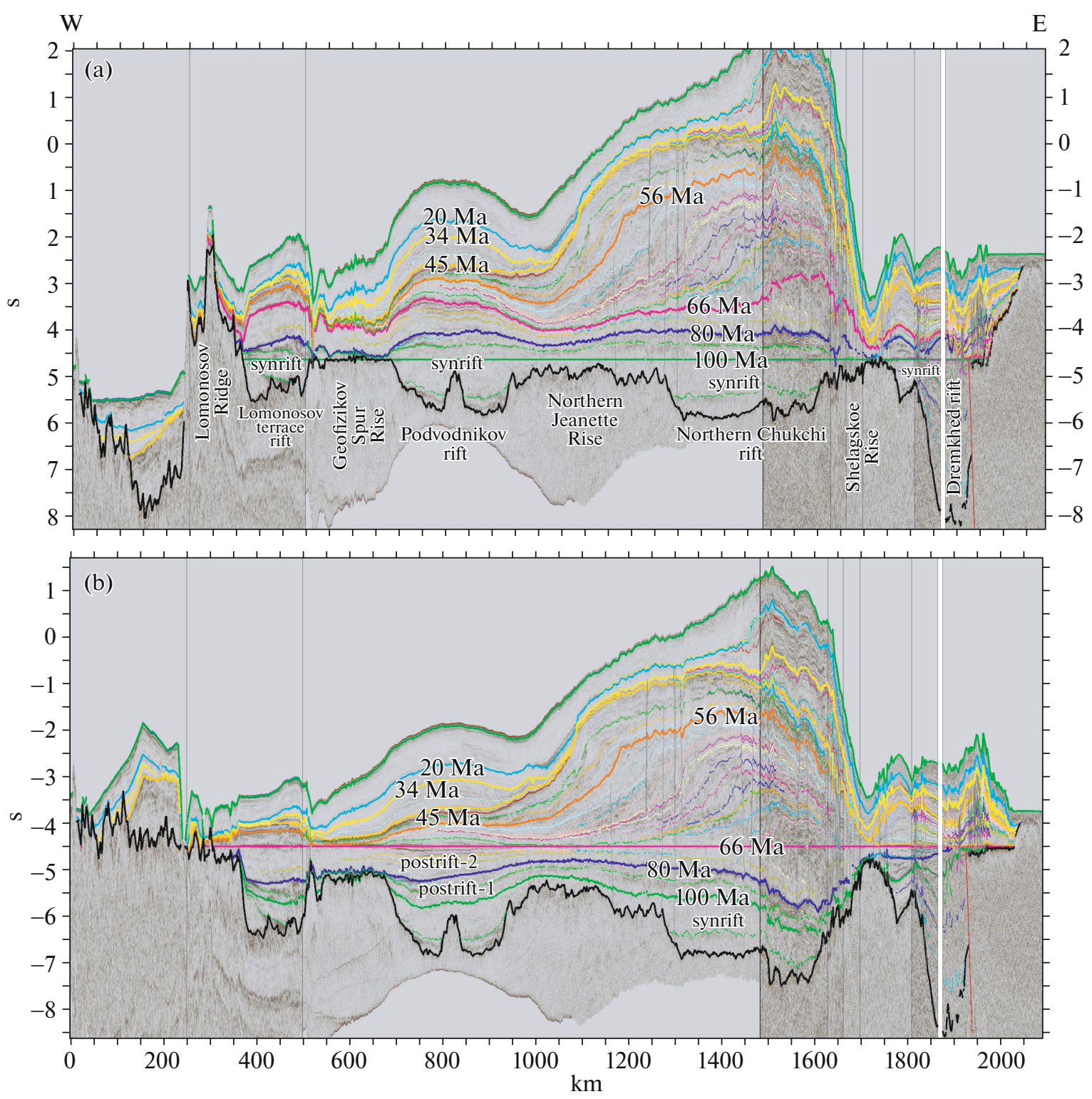

Fig. 4. Alignment to seismic boundaries of (a) $100 \mathrm{Ma}$ and (b) 80 Ma for composite profile-1. Synrift and postrift sequences are shown.

(5) the upper transgressive sequence with approximately equal thicknesses (between the horizons of $20 \mathrm{Ma}$ and the sea floor).

This seismic profile is shown with alignment to the rift-postrift boundary, which is dated at $100 \mathrm{Ma}$ (Fig. 4a). The profile shows several systems of probable rift basins: the basins of the East Siberian Sea (the Dremkhed Basin), the North Chukchi Basin, the Podvodnikov Basin, and the Lomonosov Terrace basin.

The basins of the East Siberian Sea (the Dremkhed basin, in particular) are similar to the typical continental rift troughs. Their rift nature is out of question; based on the geometry of the basins the North Chukchi Basin has a strongly thinned continental crust based on the geometry of the basins $[41,53]$; however, the opinion exists that the crust within it is locally composed of the exhumed mantle substance [25]. The basin bottom has a flattened geometry of the acoustic basement roof. In the seismic profiles, such a roof of the basement is typical of rift basins with hyperextended continental crust; examples of hyperextension were presented, e.g., in [52]. The Podvodnikov Basin is in general similar to the North Chukchi Basin. Its axial part hosts a rise that can be considered as a horst. Continental crust hyperextended by rifting is likely to be found within the Podvodnikov Basin. This is substantiated by the available geophysical data [41, 53]. Between the Podvodnikov Basin and the North Chukchi Basin there is relative Northern Jeannette Rise [49]. The 
topography of its acoustic basement is similar to the rift horst-graben structure. The basin of the Lomonosov Terrace is a typical continental rift, having a continental crust [41, 53]. The Rise of Geofizikov Spur is located between the basin of the Lomonosov Terrace and the Podvodnikov Basin, which was a shoulder rise during the rifting phase.

According to our scheme of correlations, rifting ended at approximately $100 \mathrm{Ma}$. Rifting might not start simultaneously, but we consider it probable that rifting started at the Barremian-Aptian boundary due to the collapse of the Verkhoyansk-Chukotka orogen and approximately synchronously with the basalt trap magmatism on the De Long Plateau [49].

This seismic profile is shown with alignment to the base of the lower clinoform sequence, which is dated at $66 \mathrm{Ma}$ (MBU) (Fig. 4b). The structure of the rift and post-rift sequences is found below this boundary. In the post-rift sequence, we distinguish two tectonic units, namely, lower and upper ones.

The lower post-rift unit is characterized by the occurrence of a package of bright reflectors. Its age is estimated at $\sim 100-80 \mathrm{Ma}$. It was probably formed during the Late Cretaceous climate warming [6]. Therefore, the age of the Upper post-rift unit is 80-66 Ma. The post-rift sequence has approximately equal thicknesses, which indicates a relatively uniform subsidence of the territory with the similar sedimentation. The lower unit is absent or has a small thickness on the Lomonosov Spur and Shelagskoe Rises. From this it follows that additional rift tectonic movements might have occurred in the region of these rises at 100-80 Ma.

The lower clinoform syntectonic sequence with a sharp decrease in thicknesses towards the Podvodnikov Basin and the Geofizikov Spur is clearly seen above the alignment boundary of $66 \mathrm{Ma}$. We data the age of this sequence as 66-45 Ma. The phase of tectonic orogeny corresponds to the boundary of $66 \mathrm{Ma}$ (MBU). A fragment of composite seismic profile-1 is shown (Fig. 5). This fragment clearly demonstrates the angular unconformity beneath the horizon of $66 \mathrm{Ma}$ and a probable thrust structure. The orogeny phase approximately at the Cretaceous-Paleogene boundary is well known in Alaska as the Mid-Brookian orogeny $[22,56]$. This event was also established for the Russian part of the Chukchi Sea [3, 49, 62]. A considerable tectonic uplift occurred approximately at the Cretaceous-Paleocene boundary near Wrangel Island, which was synchronously accompanied with the formation of the Wrangel-Herald thrust belt. A segment of the thrust belt is shown (Fig. 5). Consequently, the onset of formation of the Lower clinoform sequence corresponds to the phase of the Mid-Brookian uplift of the Wrangel Island area. It is evident that this event could last for millions of years; therefore, the boundary of $66 \mathrm{Ma}$ is still conventional and perhaps diachronous. The data of paleogeography and sedimentology show that the edge of the shelf and the clinoforms constantly moved within the North Chukchi Basin towards the deepwater basin, which was found in the Podvodnikov Basin. The sedimentation of distal turbidites is probable for the Podvodnikov Basin. The minimum thicknesses of deposits with ages of 66-45 Ma occur on the Geofizikov Spur Rise. They were likely to accumulate relatively deepwater condensed sediments. In the lower clinoform sequence, we record a horizon of $56 \mathrm{Ma}$. It passes in the Podvodnikov Basin along the base of the seismic stratum with bright reflectors. The stratum with bright reflectors with an age of 56-45 Ma is a marker for the significant territory of the deepwater part in the Arctic Ocean. It was formed synchronously with the epoch of relative warming in the Arctic [6], this stratum assumes special lithology (e.g., siliceous sediments are present).

A noticeable increase in the thickness of the stratum is recorded at $66-56 \mathrm{Ma}$ in the basin of the Lomonosov terrace. A Paleocene rift event, which preceded the opening of the Eurasian basin, was likely to have occurred at that time. We previously identified a rift event of this age for the region of the Lomonosov Ridge [46, 47, 49].

This seismic profile is shown with alignment to the bottom of the upper clinoform sequence, which is dated at $45 \mathrm{Ma}$. (Fig. 6a). A fragment of this seismic profile is shown for the area of the Shelagskoe Rise (Fig. 7). We consider the following main geological events (see Figs. 3, 6a, 7):

(1) the shelf edge sharply moved toward dry land at approximately $45 \mathrm{Ma}$.

(2) a small angular unconformity and erosion of the underlaying stratum are identified in the area of the Shelagskoe Rise at the bottom of this boundary.

This means that the Shelagskoe Rise was subject to the uplift phase at approximately $45 \mathrm{Ma}$. The sudden paleogeographic reconstruction at approximately 45 Ma might be caused by a short-term phase of vertical movements. A fragment of this seismic profile for the area of the Lomonosov Ridge is shown (Fig. 8). The stratum of 45-20 Ma becomes thinner and wedges out to the Lomonosov Ridge. We assume that this stratum was formed synchronously with tectonic movements.

This seismic profile with alignment to the horizon of $20 \mathrm{Ma}$ is shown (Fig. 6b). The stratum with an of 20-0 Ma has an approximately constant thickness. The probable erosion boundary is observed at the bottom of the Lomonosov Ridge area.

\section{Composite Seismic Profile-2}

The composite seismic profile-2 and its interpretation are shown (Fig. 9). The profile goes from the shelf of the East Siberian Sea through the North Chukchi Basin and the margin of the Podvodnikov Basin and intersects the Mendeleev Rise and the Toll Basin. The 


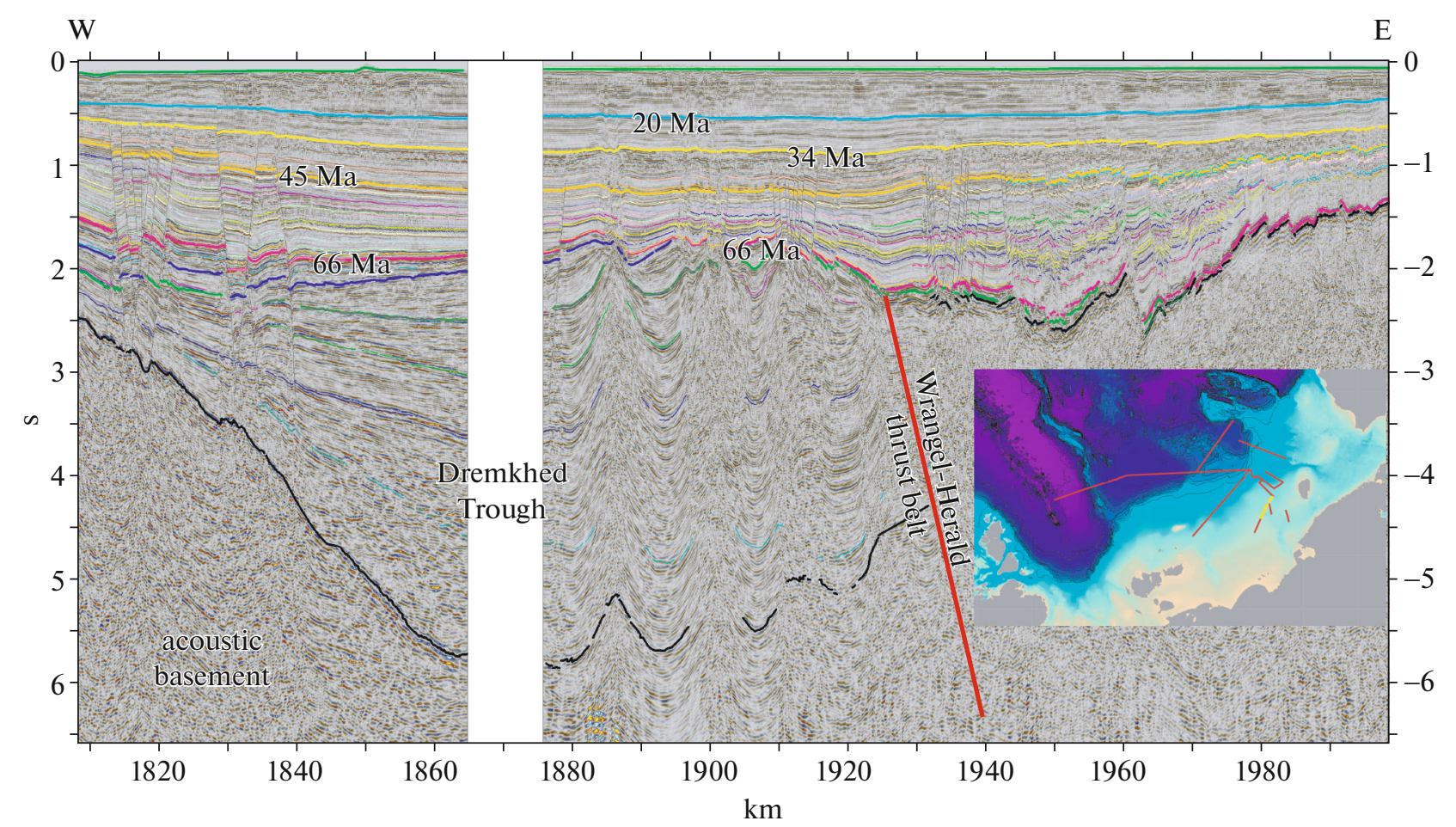

Fig. 5. Fragment of the composite seismic profile-1. The shown are position of profile-1 (map in inset); angular unconformity at $\approx 66 \mathrm{Ma}$ (for the Dremkhed Trough); folds with consedimentary growth (below the angular unconformity); diapir-like bodies (probably, clayey diapirs in anticlinals); Wrangel-Herald thrust belt at $\approx 66 \mathrm{Ma}$.

profile partially coincides with profile-1 in the area of the Kucherov terrace, which is important for correlation of the boundaries at the different profiles. For profile-2, the following tectonostratigraphic units (seismic sequences) are identified with the following conventional names:

(1) the synrift sequence-between the acoustic basement and the horizon of $100 \mathrm{Ma}$;

(2) the postrift sequence-between the horizons of 100 and $66 \mathrm{Ma}$;

(3) the lower clinoform syntectonic sequence and its extensions towards the Mendeleev Rise and the Chukchi Plateau-between the horizons of 66 and $45 \mathrm{Ma}$;

(4) the upper clinoform syntectonic sequence and its extensions-between the horizons of 45 and $20 \mathrm{Ma}$;

(5) the upper transgressive sequence with approximately equal thicknesses between the horizons of $20 \mathrm{Ma}$ and the sea bottom.

In the lower synrift sequence, four main basins are clearly identified. From west to east, they are the Manskii and North Melville Basins (the basins of the East Siberian Sea), the North-Chukchi and Toll Basins. The Manskii and North Melville Basins are divided by the Henrietta Rise. The Makhov Rise divides the North Melville and North Chukchi Basins. The Mendeleev Rise divides the North Chukchi Basin with the Podvodnikov Rise margin and the Toll Basin.
It is clearly seen that the Manskii and North Melville Basins have a rift nature (Fig. 9c). The main rifting phase occurred between the boundaries of 125 and $100 \mathrm{Ma}$. However, the seismic data make it possible to assume that there were several phases of normal fault formation in these basins until Middle-Late Eocene. The characteristics for the North Chukchi Trough and the Podvodnikov Basin can be the same as for composite profile-1. The northern part of the North Chukchi Trough may encompass clinoforms with ages of $\sim 80-66$ Ma (Fig. 9c).

The Toll Basin has one important feature in its lower part: there is a probable rift-postrift boundary $(100 \mathrm{Ma})$ below which the packages of reflectors dip in the same direction towards the Mendeleev Rise [46] (Fig. 10). They are known as Seaward Dipping Reflectors (SDRs) and are typical of volcanic passive continental margins [28]. For the Mendeleev Rise area, we identified them only in this profile [46] and did not exclude that this was the effect of seismic data processing. Recently, American colleagues published a profile that was almost parallel to our profile and is located slightly southward [32]. It clearly shows similar SDRs with the same polarity [32]. SDRs are primarily composed of synrift basalts, which occurs during continental rifting over the mantle plumes $[15,28]$. The presence of SDRs in the Toll Basin at two profiles at least confirms our hypothesis that this is an AptianAlbian continental rift basin [46, 49]. It extends 

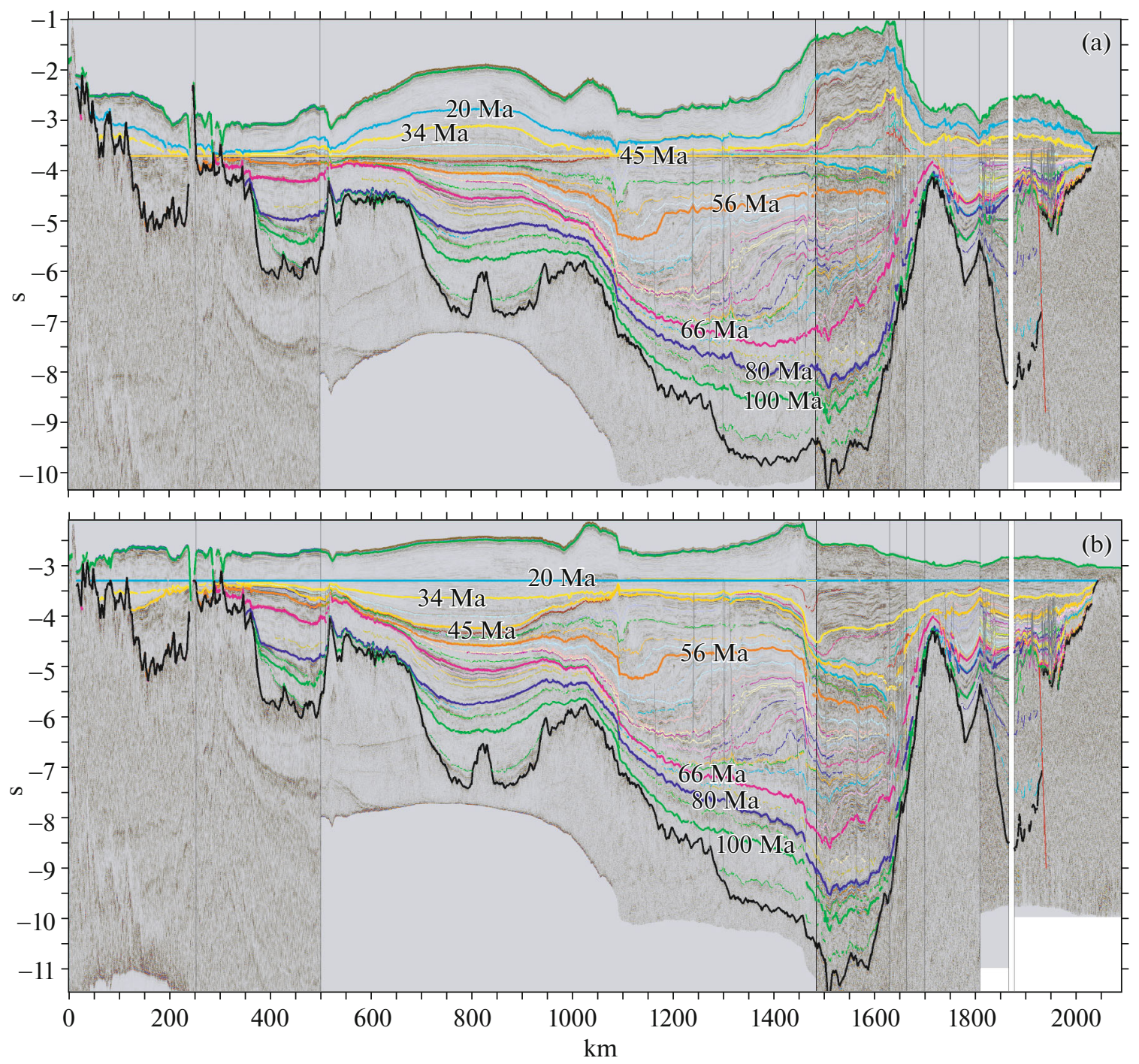

Fig. 6. Alignment to seismic boundaries of (a) $45 \mathrm{Ma}$ and (b) $20 \mathrm{Ma}$ for composite profile-1.

orthogonally to the trend of the spreading axis in the Canada Basin, which indicates that the Canada Basin and the Toll basin were formed in the different geodynamic environments.

The Mendeleev Rise deserves a special study; here, we confine ourselves to a brief discussion. At the profile, the basement topography has horst-graben geometry. This assumes both horst-graben geometry of the rise crust and intersection of the volcanic structures by the profile. On the slopes, the Mendeleev Rise is covered by boundaries of $80 \mathrm{Ma}$ and younger. For the central part of the rise, the seismic data are obviously not enough for the accurate seismic stratigraphy of the lower part of the section. The available sampling data for three slopes of the Mendeleev Rise show that the acoustic basement may include deformed sedimentary Paleozoic sequences with Ordovician-Devonian fauna according to the data of S.G. Skolotnev (Insti- tute of Geology, RAS) [57], a subhorizontal sedimentary cover starts from the Aptian (Barremian-Aprian) [57]. The dykes with isotope ages of approximately 110-115 Ma intrude the Paleozoic deformed sediments. Assumedly, the large-scale continental rifting and plume magmatism with a peak of activity at approximately $115-110 \mathrm{Ma}$ was likely to occur in the Mendeleev Rise area in the Aptian-Albian. Some data indicate that volcanism occurred on the Alpha-Mendeleev Rise, at least locally, at $\approx 90-80$ Ma [21, 64]. Our profile shows that the Mendeleev Rise has a clearly pronounced asymmetry, with a steeper slope towards the Podvodnikov Basin. On the west, the rise is limited by the Marginal-Mendeleev large normal fault [49]. This fault, at least as a steep slope in the paleotopography, has existed from $66 \mathrm{Ma}$ (or earlier) until present. We believe that it activated from the boundary of $45 \mathrm{Ma}$ and was active in the Late Cenozoic from $20 \mathrm{Ma}$. 


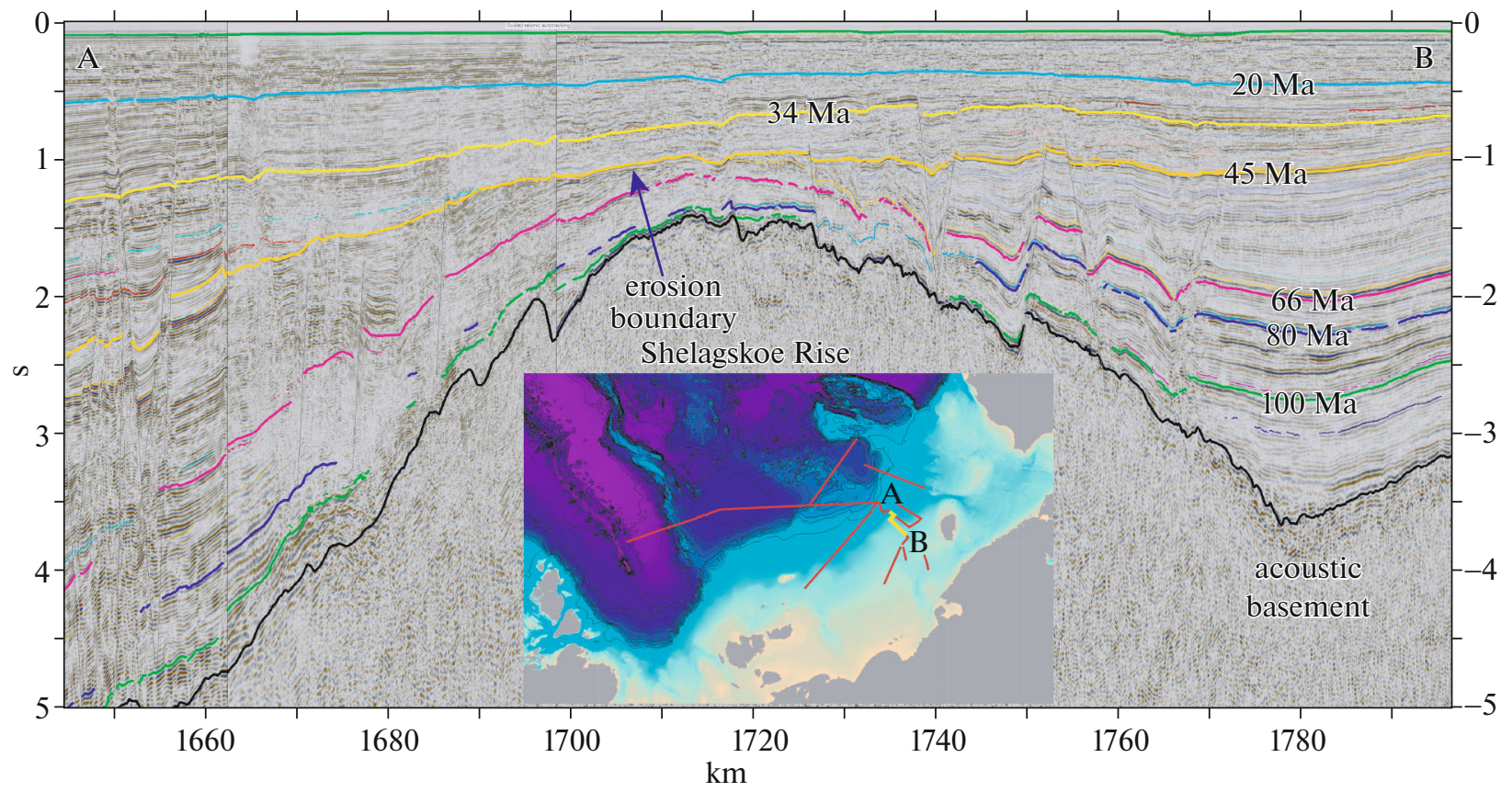

Fig. 7. A fragment of composite seismic profile-1. The shown are position of this profile (map in inset); erosion surface (for the Shelagskoe Rise, at the base of the boundary at $45 \mathrm{Ma}$ ).

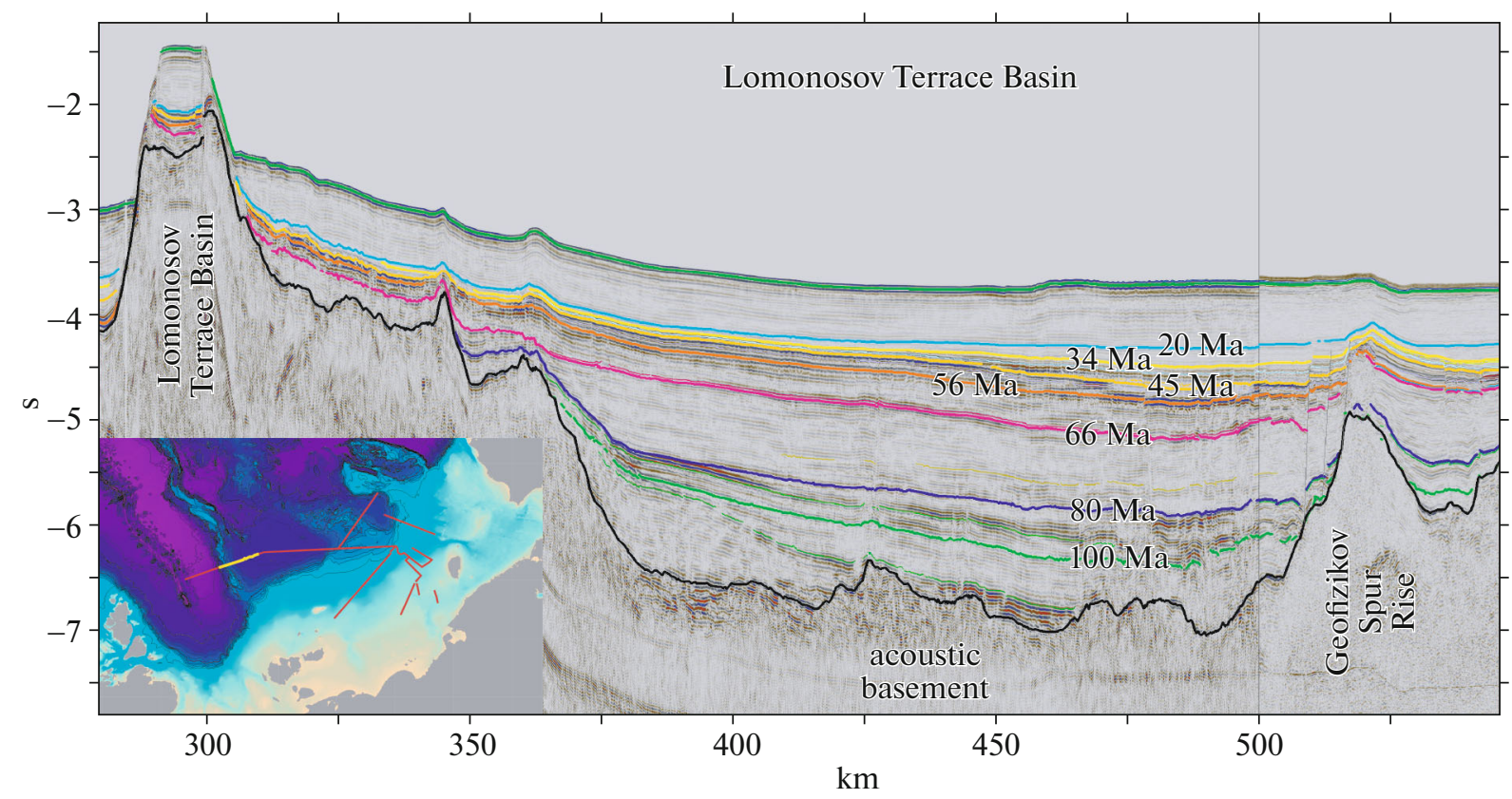

Fig. 8. A fragment of composite seismic profile-1. The shown are the position of profile-1 (map). The Lomonosov Terrace basin and the stratum with an age of 45-20 Ma (gradually wedges out towards the Lomonosov Ridge) are delineated.

The Mendeleev Rise has an Aptian-Albian-Late Cretaceous age of formation. The seismic profiles do not display evidence of oceanic crust spreading. Our composite profile-2 illustrates that the lower clinoform sequence with a bottom age of approximately $66 \mathrm{Ma}$ was formed after the formation of the Mende- leev Rise structure, which is an argument in favor of our dating of this sequence.

These data do not confirm the Aptian or the more ancient age of the basement of the clinoform sequence that was assumed in $[23,54]$. At composite profile-2, on the shelf of the East Siberian Sea below the horizon 
A

B
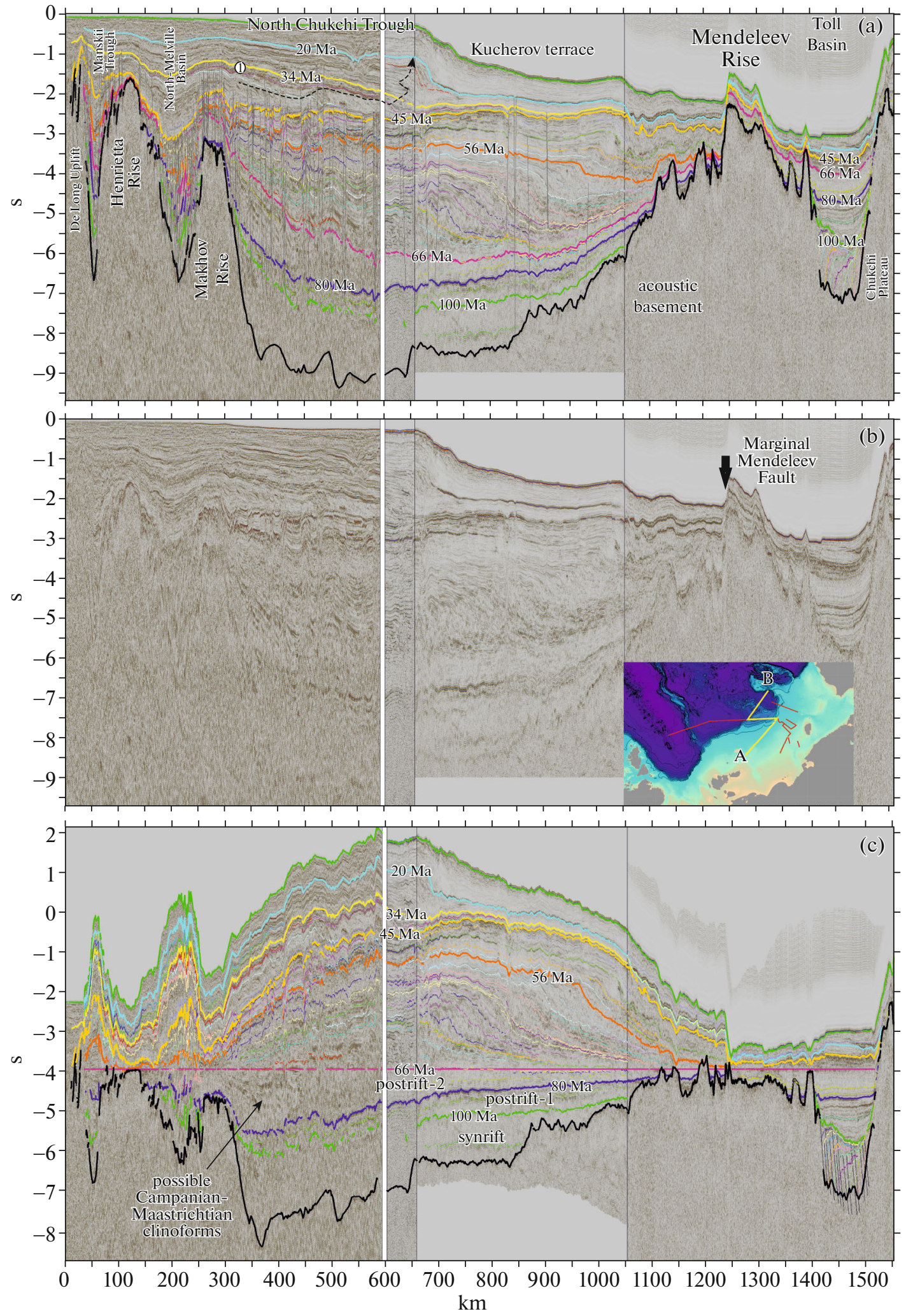

Fig. 9. The composite seismic profile-2: (a) profile with interpretation (number 1 in the white circle is a level of chaotic horizon); (b) profile without interpretation; (c) profile-2 with alignment to the boundary of $66 \mathrm{Ma}$. The shown are position of profile-2 (map in inset); conventional geological age, Ma (numbers at boundaries); horizontal scale, $\mathrm{km}$ (numbers at the horizontal scale); vertical scale, s (double time); and position of the paleoshelf edge based on the geometry of clinoforms (dashed line with an arrow). 


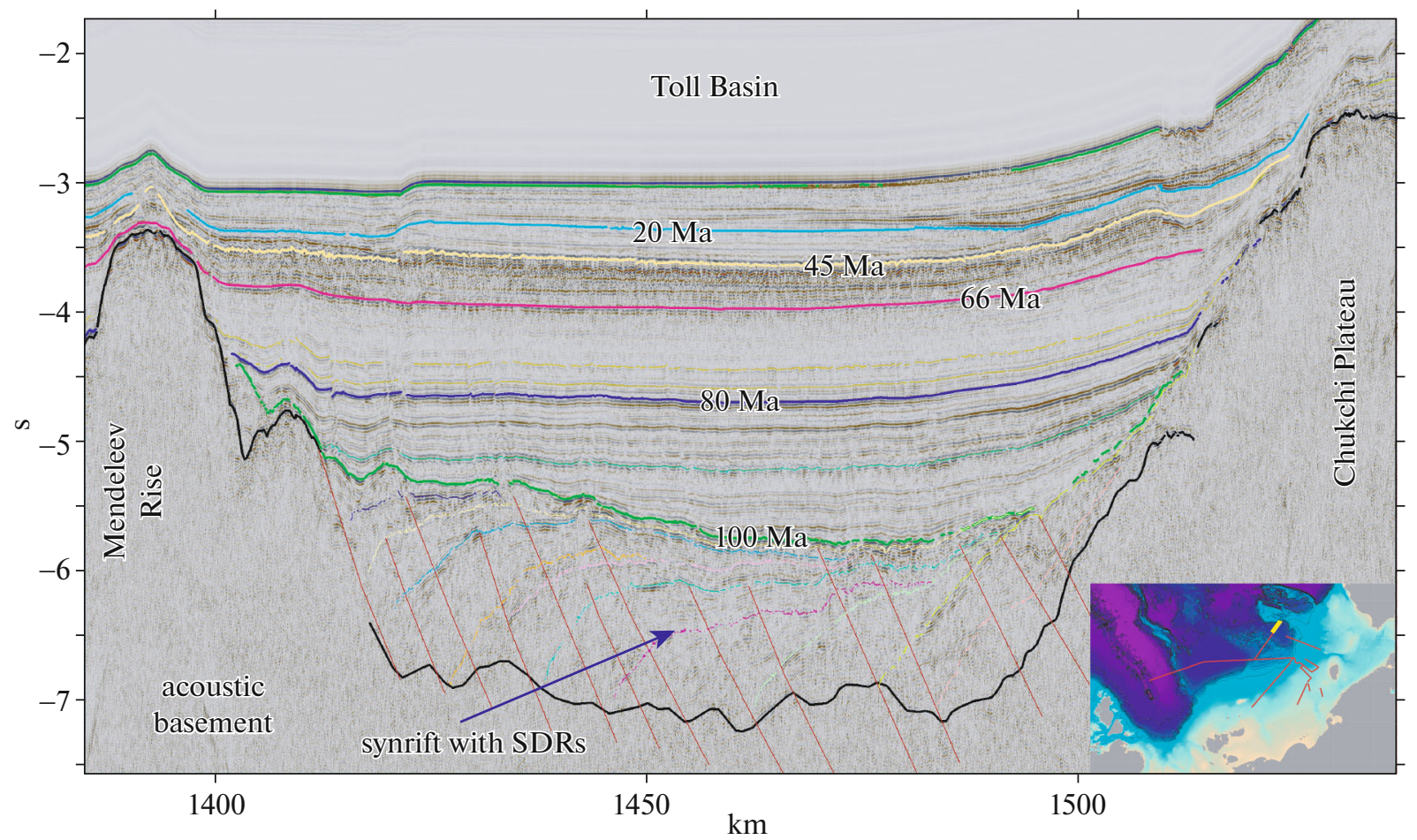

Fig. 10. A fragment of composite seismic profile-2 for the Toll Basin area. Reflectors are shown (below the boundary of $100 \mathrm{Ma}$ ) with an inclination to the same side.

of $34 \mathrm{Ma}$, we clearly recognize a chaotic horizon that has a regional extent and is important as a reference horizon for seismic stratigraphy of the region. The conventional age of the horizon with respect to the position at the section is $37-34 \mathrm{Ma}$. Below the chaotic horizon over the boundary of $45 \mathrm{Ma}$ a clearly defined fast progradation of the clinoform sequence occurs and the level of the chaotic horizon is characterized by a sharp transition to aggradation of the clinoform sequence (Fig. 9). Therefore, it is highly probable that a regional tectonic event with a change in paleogeography occurred during the formation of the chaotic horizon.

\section{Composite Seismic Profile-3}

Composite seismic profile- 3 and its interpretation are shown (Fig. 11). The profile goes from the Podvodnikov Basin through the Mendeleev Rise and the Toll Basin and goes into the North Chukchi Basin. Profile-3 is shown to correlate with the seismic stratigraphy at the composite profiles, that is, profile- 1 and profile-2. The presented composite profiles confirm that our boundaries are consistent for the two different basins and rises of Eastern Arctic.

\section{Composite Seismic Profile-4}

Northward of Wrangel Island, the Umkilir trough was identified as a Cenozoic structure [42, 46, 49]. To clarify its nature and age, we constructed a composite seismic profile that starts in the North Chukchi
Trough, intersects the Umkilir Trough, goes into the Shelagskoe Rise, and returns to the North Chukchi Trough along another line (Fig. 12). In profile-4, the seismic horizons are drawn on the network of the profiles from other sections. The many faults and separate horizons that wedged out do not allow making unambiguous correlations, but all correlations show that the Umkilir Trough is a Cenozoic half-graben. It has lower and upper synrift sequences located below and above the conventional boundary of $45 \mathrm{Ma}$. Rifting definitely ended before the boundary of $34 \mathrm{Ma}$ (the time that rifting ended is $\approx 37 \mathrm{Ma}$ ). We determined that the Umkilir Trough is a rift with an age of $\sim 45 \mathrm{Ma}$. On the American shelf of the Chukchi Sea near Alaska lies the Hope Basin. The rift nature and the Eocene age were justified for it [44]. In the lower portion of the basin section are volcanites with an age of $42.3 \mathrm{Ma}$ from the drilling data [44]. The Hope and Umkilir basins were likely to form simultaneously.

\section{SYSTEMS OF REGIONAL LOW-AMPLITUDE NORMAL FAULTS OF $\approx 45$ MA}

We identified many low-amplitude normal faults that were active at approximately $45 \mathrm{Ma}$ in the area of the North Chukchi Trough and the troughs in the East Siberian Sea, (Figs. 3, 7, 9). A fragment of the profile with such normal faults is shown (Fig. 13).

Most of the normal faults intersect the boundary of $45 \mathrm{Ma}$ and do not reach the boundary of $34 \mathrm{Ma}$. It fol- 


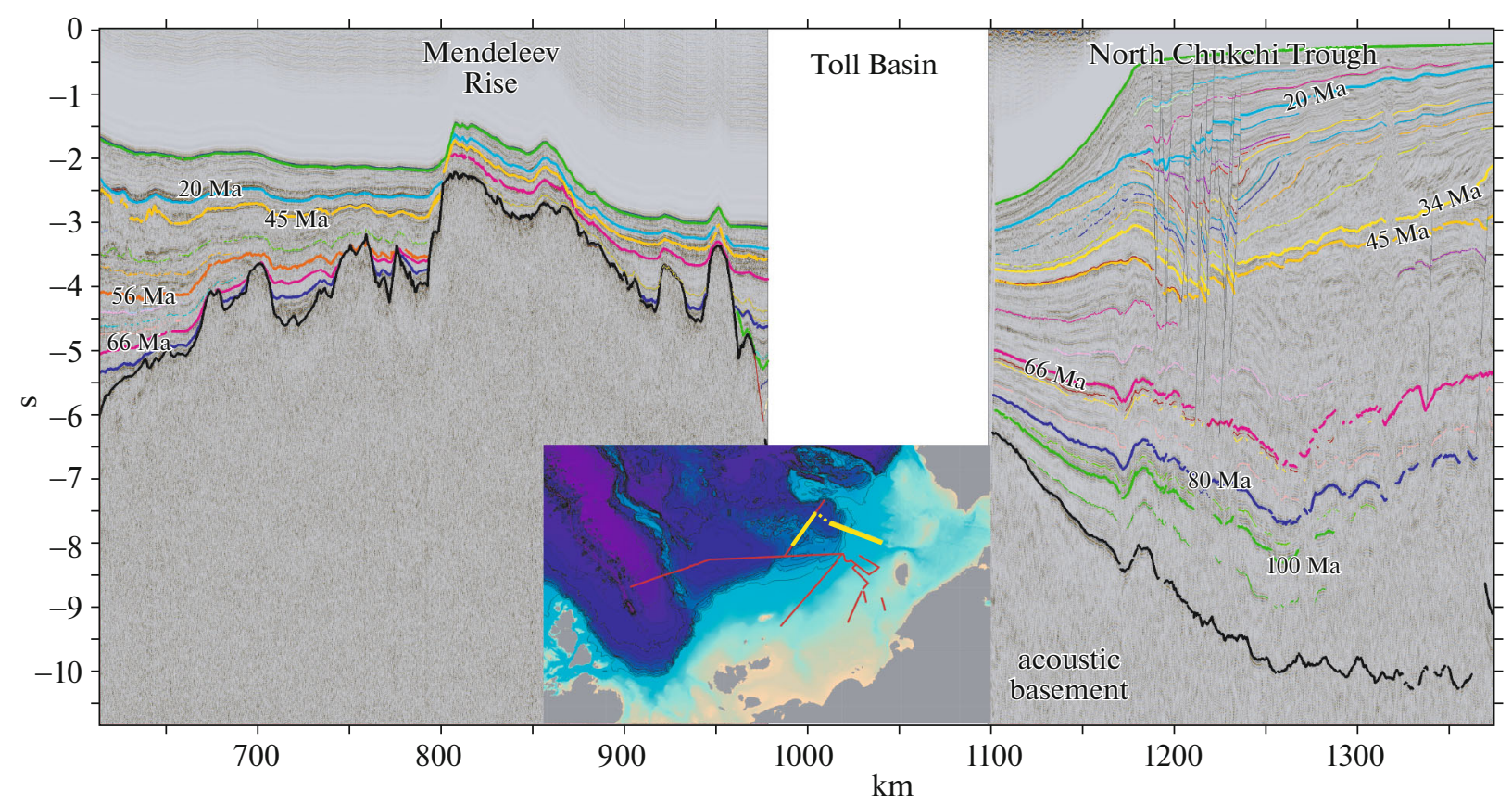

Fig. 11. The composite seismic profile-3. The shown are the position of profile-3 (map in inset); conventional geological age, Ma (numbers at boundaries); horizontal scale, in km; vertical scale, s (double time).

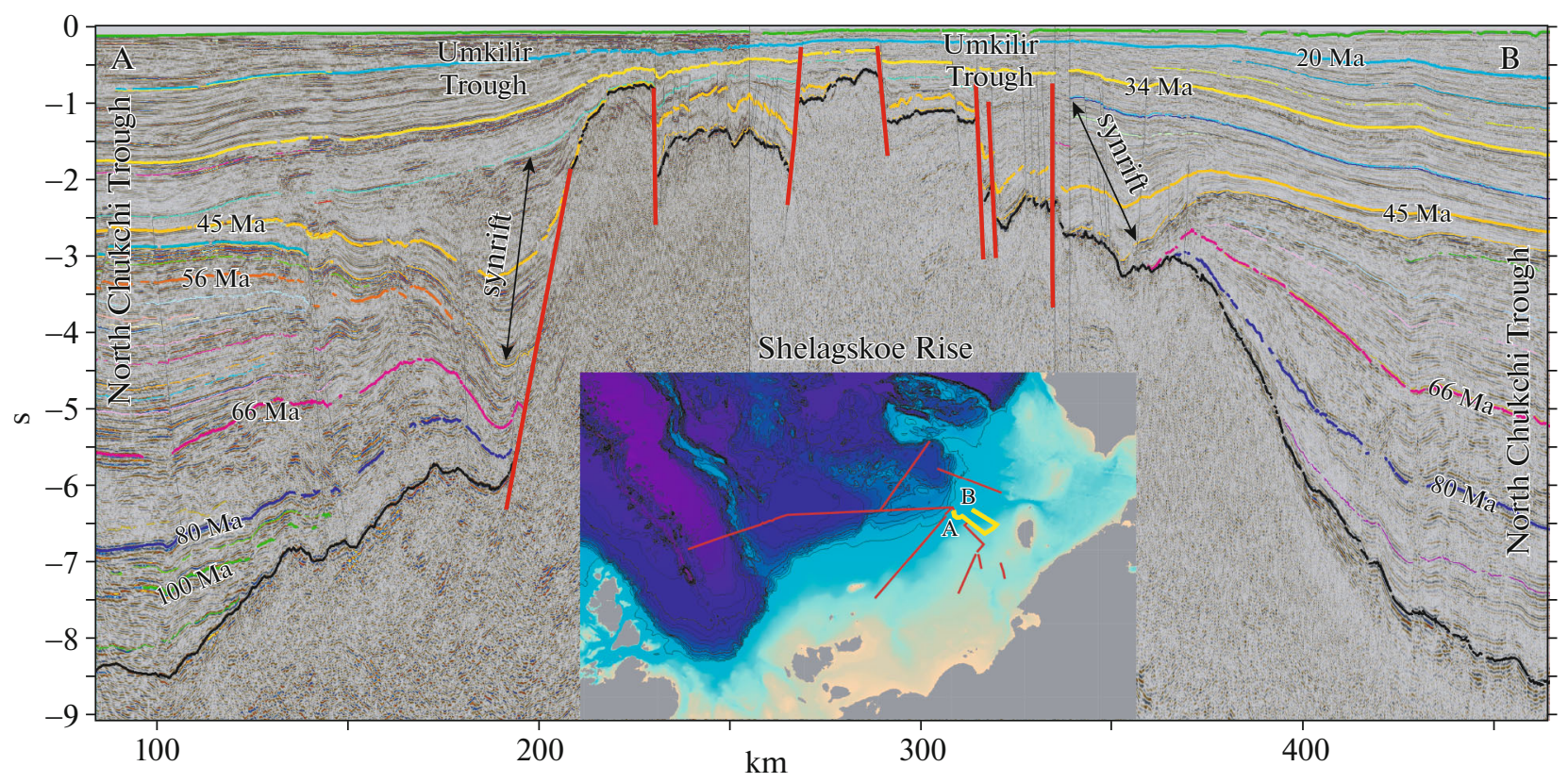

Fig. 12. The composite seismic profile-4. The shown are the position of profile-4 (map in inset); conventional geological age, Ma (numbers at boundaries); horizontal scale, in km; vertical scale, s (double time).

lows that the phase of regional extension or transtension occurred at $\approx 45 \mathrm{Ma}$. The time of formation of the Umkilir Trough also corresponds to $\approx 45 \mathrm{M}$.

\section{Composite Seismic Profile-5}

Composite profile-5 and its interpretation are shown (Fig. 14). The profile is oriented in parallel to composite profile- 1 and is located in the area of the
Pegtymel and Dremkhed Troughs. In profile-5, we identified a thrust (a part of the Wrangel-Herald thrust belt) and corresponding angular unconformity. In the area of the thrust, the stratum with a bottom somewhat more ancient than $45 \mathrm{Ma}$ with an angular unconformity rests on Cretaceous deposits and on the basement. In the area of the Dremkhed Trough, the horizons of $66 \mathrm{Ma}$ and some others almost converge in 

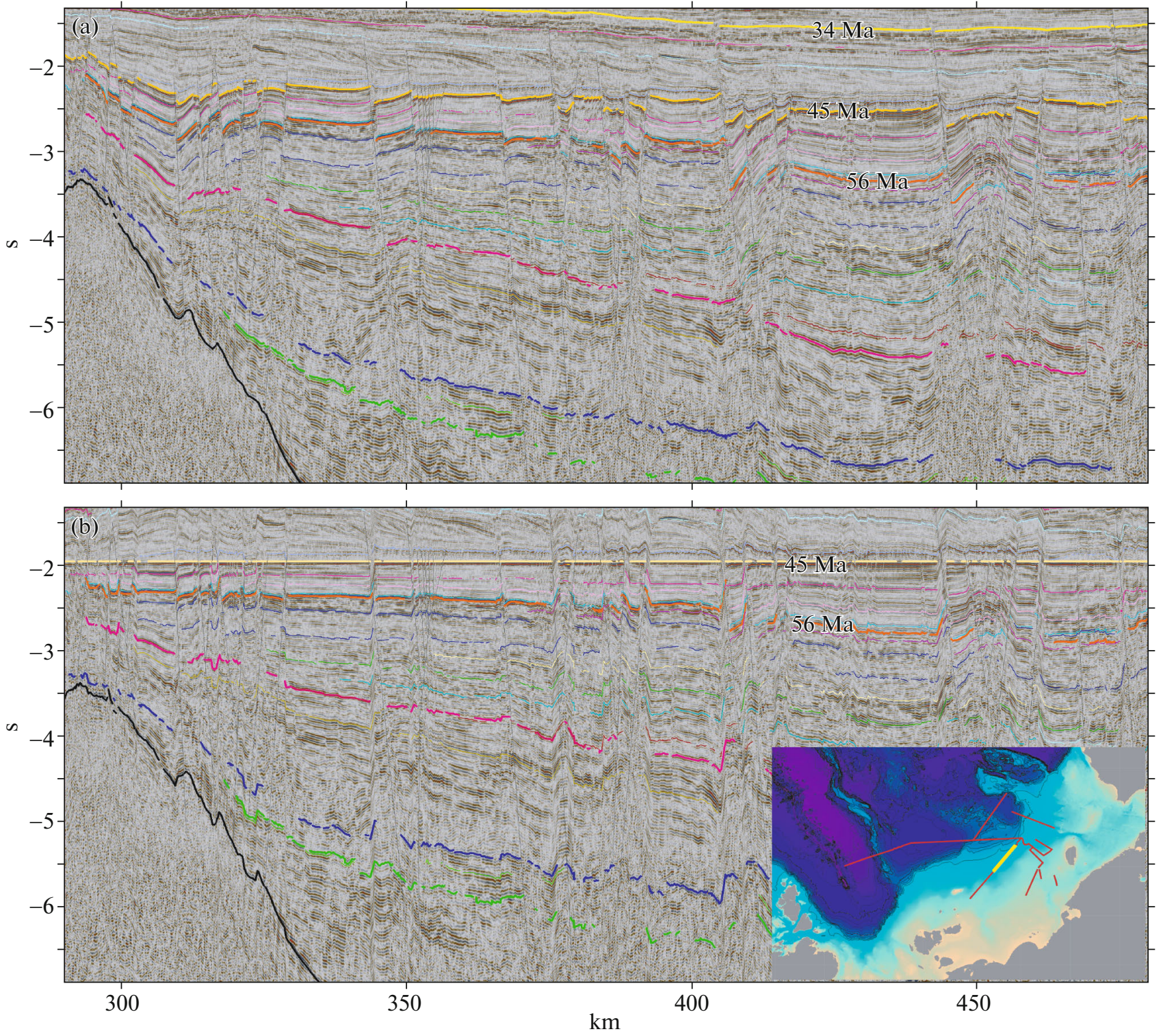

Fig. 13. (a) A fragment of composite seismic profile-1 and (b) alignment to the boundary of 45 Ma. Shown: the position of the profile (map); most low-amplitude normal faults younger than 45 Ma intersect the boundary of 45 Ma, but do not intersect the boundary of $34 \mathrm{Ma}$.

the direction towards the main thrust. Composite profile-1 (Figs. 3, 5) shows that the main phase of folding was close to $66 \mathrm{Ma}$ (MBU). We may assume that for composite profile-5, the main phase of thrust formation corresponds to the MBU unconformity and has an age of $66 \mathrm{Ma}$. The thrust block is overlaid with the deposits that are somewhat more ancient than $45 \mathrm{Ma}$; hence the probability is confirmed that this block after 66 Ma was uplifted and subject to erosion. This profile also shows that the boundary of $45 \mathrm{Ma}$ is intersected by numerous normal faults that are more ancient than the boundary of $34 \mathrm{Ma}$ and proves that normal faults actively formed in the thrust area at $\approx 45 \mathrm{Ma}$. The epoch of normal fault formation at $\approx 45 \mathrm{Ma}$ is synchronous to the time of formation of the Umkilir graben.

\section{Fragment of Seismic Profile-6}

A fragment of the seismic profile in original and with alignment to a seismic horizon of $20 \mathrm{Ma}$ is shown, which is an example of the inverted Cretaceous Pegtymel rift (Fig. 15). The boundaries for profile-6 are associated with our boundaries in the other profiles we presented. Two main angular unconformities at the base of the boundary, corresponding to 34 and $20 \mathrm{Ma}$, are shown.

The paleorift compression began at $\approx 34 \mathrm{Ma}$ and completed at $\approx 20 \mathrm{Ma}$. The compression zone is confined to the Wrangel-Herald thrust belt and its western extension, which made it possible to identify the phase of Oligocene-Early Miocene compression in 

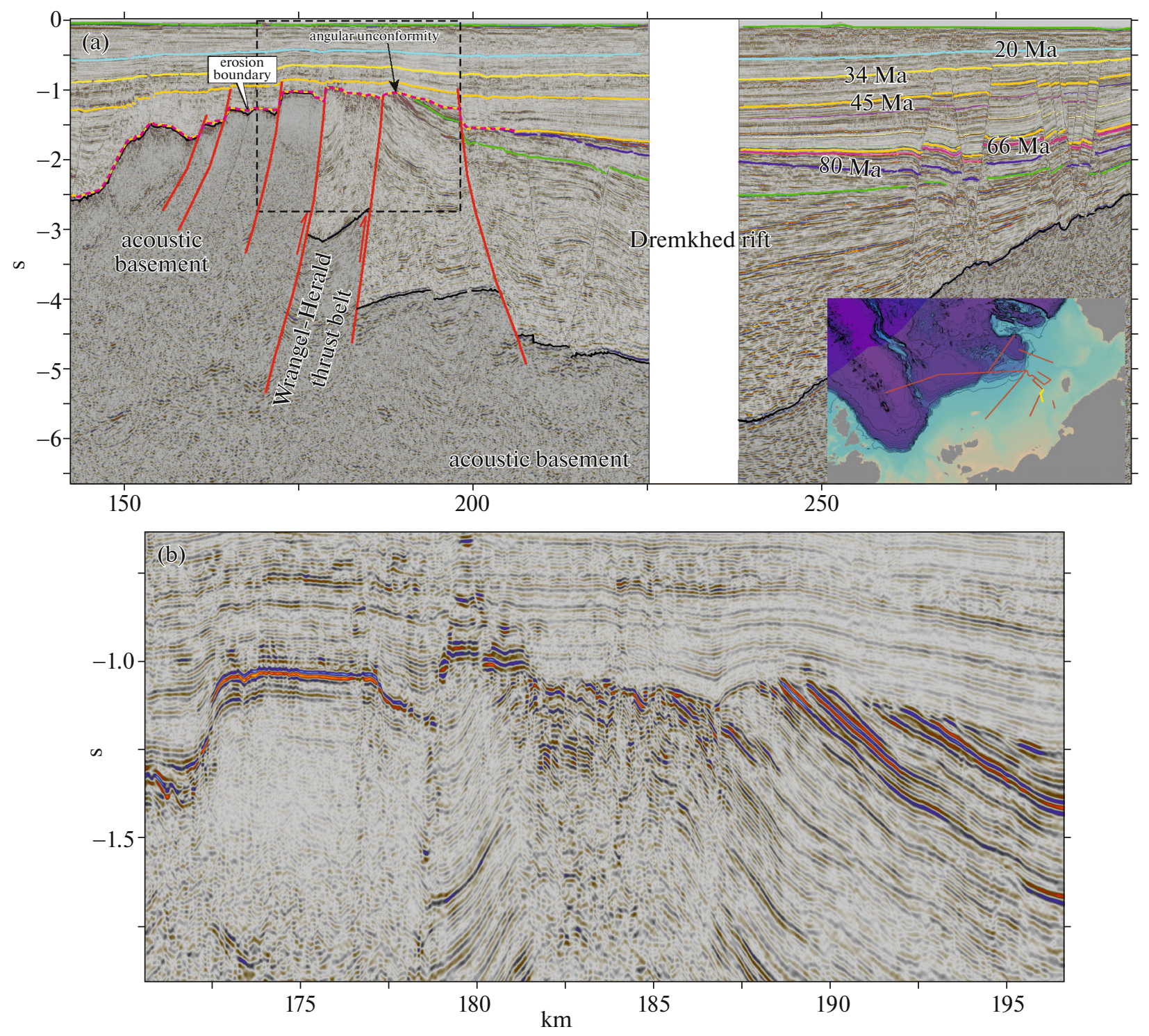

Fig. 14. The composite seismic profile-5: (a) fragment of profile-5; (b) position of profile-5 (square on the profile-5 for location). The shown are conventional geological age, Ma (numbers at boundaries); horizontal scale, in km; vertical scale, s (double time).

this region, which was broadly manifested in the South Chukchi Basin [3].

\section{A Fragment of Seismic Profile-7}

A fragment of a seismic profile that is located eastward of New Siberian Islands and intersects the western extension of the Wrangel-Herald thrust belt is shown [8, 24, 46, 49] (Fig. 16). Northward of the thrust belt, we identified the Zhokhov Cretaceous foredeep [24, 25], as shown in profile-7. According to our correlation of the seismic profile network, this foredeep is overlaid with the stratum of the Aptian-Albian deposits; similar conclusions were included in [8]. It is highly likely that the foredeep has a Late Jurassic-Neocomian age and that this foredeep is approximately of the same age as the Pre-Verkhoyansk foredeep. Southward of the foredeep in the seismic profile we see the sub-Aptian folded sequence, which is probably exposed on the New Siberian Islands and is represented by the deposits from Ordovician to Triassic or Jurassic $[8,46]$. Profile-7 shows the Aptian-Albian rifts. Rifting began in the Eastern Arctic after the completion of the Verkhoyansk-Chukotka folded region.

\section{RESULTS AND DISCUSSION}

We recognized the naturally prominent seismic sequences (mega-sequences) or tectono-stratigraphic units for the shelf of the East Siberian and Chukchi Seas and for the adjacent deepwater segments of the 

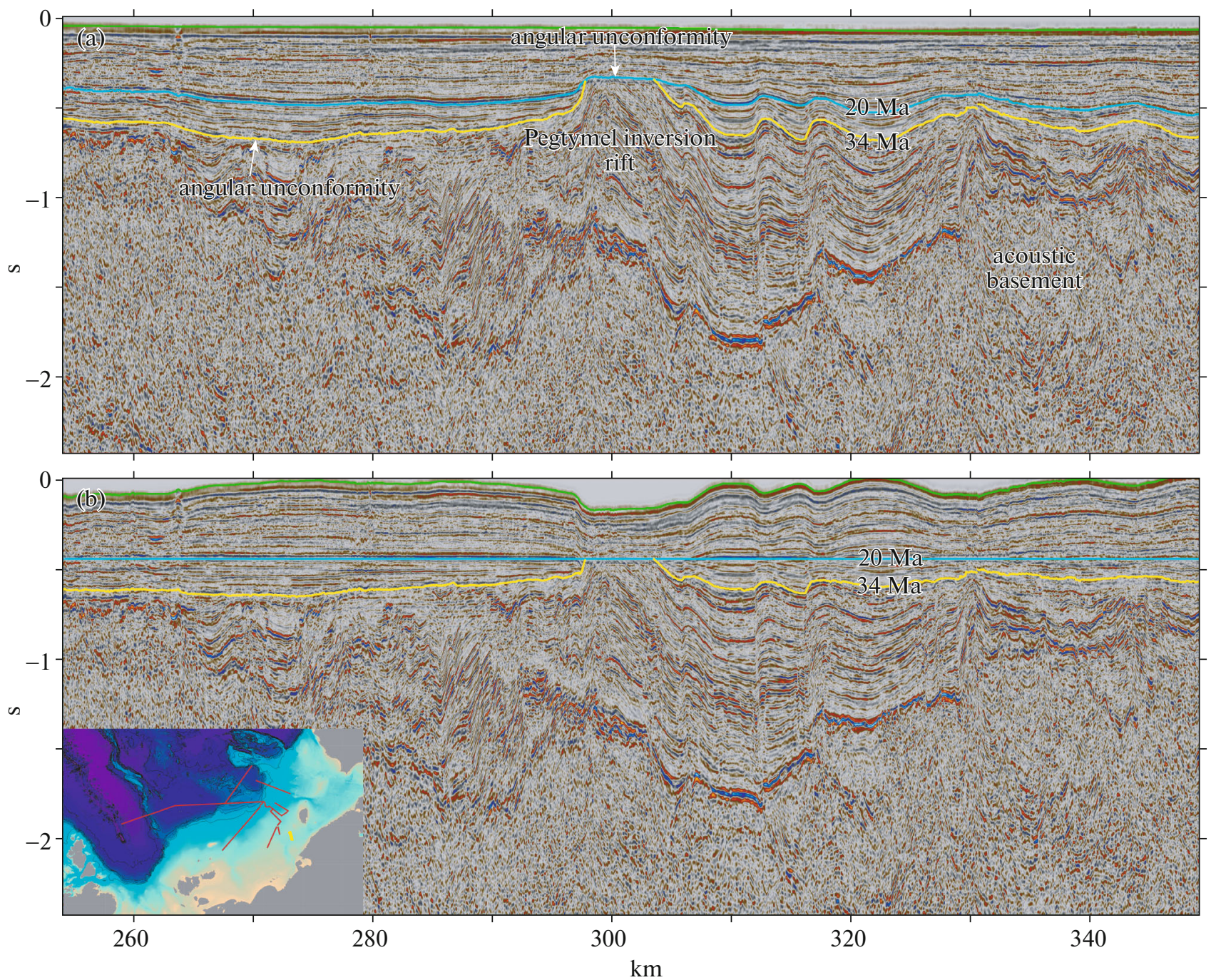

Fig. 15. The composite seismic profile-6. (a) profile with interpretation; (b) profile with alignment to the boundary of 20 Ma. The shown are the position of profile-6 (map in inset); conventional geological age, Ma (numbers at boundaries); horizontal scale, $\mathrm{km}$ (numbers at the horizontal scale); vertical scale, s (double time); angular unconformity (34, $20 \mathrm{Ma}$ ).

Arctic Ocean. We identified the following main tectonostratigraphic units with conventional ages that can be refined:

- 164-125 Ma-a foredeep sequence (foreland basin);

- 125-100 Ma-synrift-1sequence;

-100-80 Ma-postrift-1 sequence;

- 80-66 Ma-postrift-2 sequence;

- 66-45 Ma-syntectonic sequence-1 (66-56 Ma, the lower part of syntectonic sequence- 1 corresponds to synrift-2 sequence);

- 45-34 Ma-syntectonic sequence-2 (or synrift-3);

- 34-20 Ma-syntectonic sequence-3;

- 20-0 Ma-sequence of a regional cover.

We identified a sequence of the Zhokhov foredeep that is located between the New Siberian Islands and De
Long islands, i.e., between the Mesozoides of the New Siberian Islands and the De Long Uplift with Timanian and Caledonian basement. We assume that the Zhokhov foredeep extends northward of the Wrangel-Herald thrust belt [24]. The Zhokhov foredeep is shown in our seismic profiles, it is overlaid by the sediments that have an Aptian-Albian age according to our correlations and [8]; therefore, the foredeep can be Late Jurassic-Neocomian. In the area of the Lyakhovsky Islands and on Stolbovoi Island, the deposits of the Volgian-Neocomian foredeep were identified [39]. We believe that the Zhokhov foredeep basin is of the same age as syntectonic sediments of the Lyakhovsky Islands and the extension of the Late-Jurassic-Cretaceous Pre-Verkhoyansk foredeep. The common belt of foredeeps that constraints the Mesozoides of the Verkhoyansk-Chukotka region and the Brooks Range orogenic belt emerges (Fig. 17). It includes 


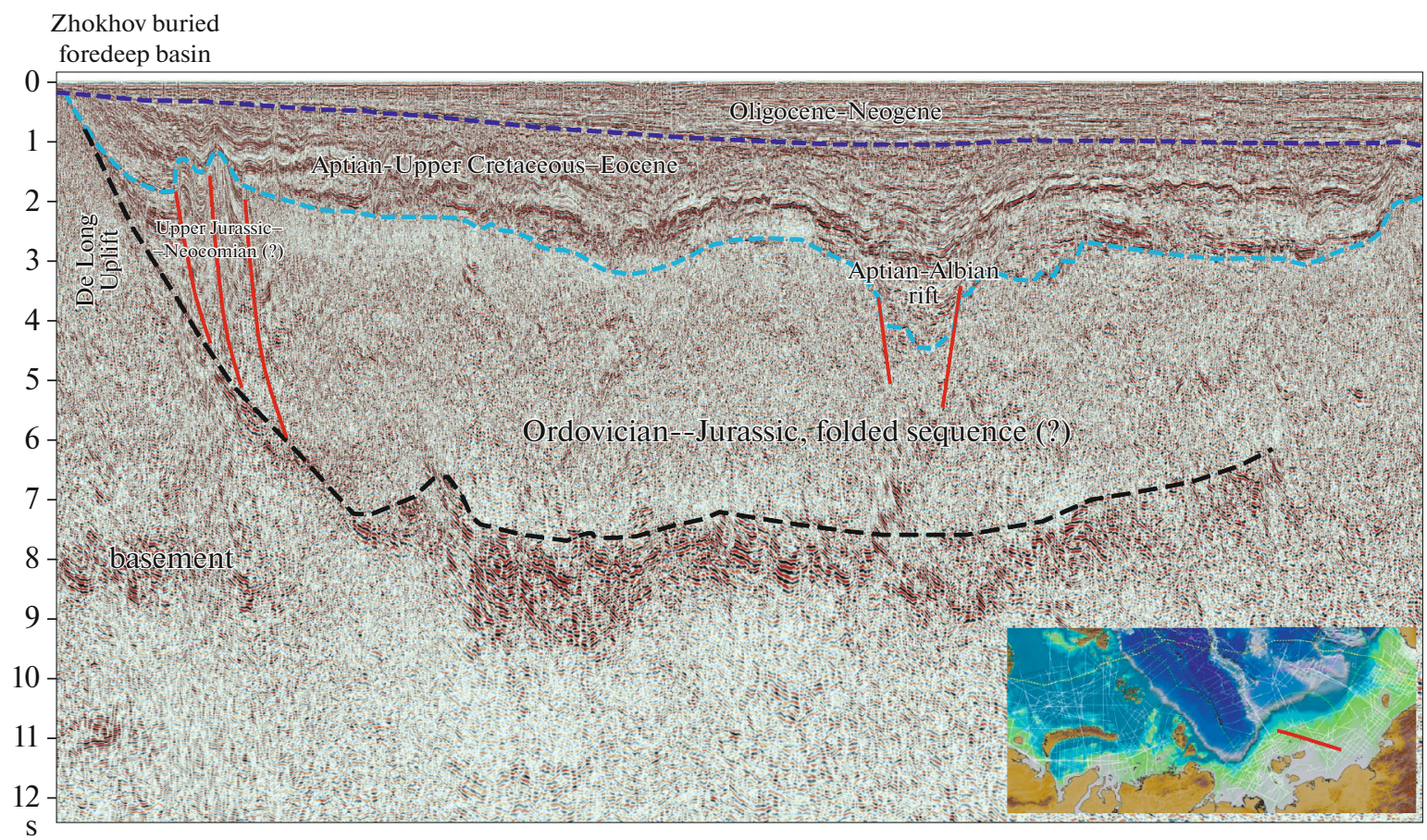

Fig. 16. Seismic profile-7.

such known fragments as the Pre-Verkhoyansk foredeep, the Zhokhov foredeep basin, the North Wrangel foredeep basin, and the Colville foreland basin in Alaska. Therefore, a continuous continental massif that included the Siberian platform and Hyperborean continent existed westward and northward of Mesozoides from the Verkhoyansk-Chukotka region during the Late Jurassic and the Early Cretaceous [10, 13].

The synrift-1 sequence (125-100 Ma) is clearly identified on the shelves of the East Siberian and Chukchi Seas (North Chukchi, North Melville, Manskii Troughs, etc.). It is also manifested in the deepwater Podvodnikov basin, Lomonosov Terrace, and Toll basin (Fig. 18). The rifting onset corresponds in time to trappean magmatism on the De Long Uplift. The geometry of the rift basins shows that a hyperextended continental crust was formed in the NorthChukchi Trough during rifting. Hyperextensions existed also in the Podvodnikov and Toll basins. The occurrence of SDR type reflector packages in the Toll basin indicates that continental rifting occurred over the mantle plume. We determined that the rifting ended at $100 \mathrm{Ma}$.

Postrift- 1 and postrift- 2 sequences regionally overlay all areas with Aptian-Albian rifting and have almost equal thicknesses. This indicates that the entire region had a thermal postrift subsidence. Some rift faults could be active at 100-80 Ma.

Syntectonic sequence-1 (66-45 Ma) is best manifested in the North Chukchi Basin. This sequence is certainly a single mega-sequence and is attributed to the phase of uplift and significant erosion of the territory southward of the North Chukchi Trough. The MBU angular unconformity ( $\sim 66 \mathrm{Ma})$ is clearly seen along the Wrangel-Herald thrust belt and its western extension. The MBU angular unconformity in the Dremkhed Trough indicates the consedimentation growth of the folds (Fig. 5). This points to the fact that the epoch of folded strains could have lasted for some time (the first few million years). This syntectonic sequence has strongly changing thicknesses and facies. We may assume that the continental sedimentary deposits facially transform to the shelf strata in the area of the North Chukchi Trough from south to north and then to slope and deepwater strata, including turbidites, and a relatively deepwater sea basin was located in the area of the Podvodnikov Basin (Paleocene).

The synrift-2 sequence (66-56 Ma) was identified on the eastern slope of the Lomonosov Ridge in the Lomonosov Terrace basin (Figs. 3, 4, 6). The rifting phase was broadly manifested in the area of the Laptev Basin and along the Lomonosov Ridge [27, 46, 47, 49] and preceded the opening of the Eurasian ocean basin.

Syntectonic sequence-2 (or synrift-3) (45-34 Ma) is separated from syntectonic sequence- 1 by a sudden jump of the shelf edge (the edge of the clinoform sequence) towards the continent. This rapid transgression with an age of $\sim 45 \mathrm{Ma}$ can be explained either by a sudden rise of the sea level or by fast vertical tectonic movements. The Umkilir graben in the south of the North-Chukchi Trough was formed at approximately $45 \mathrm{Ma}$ (Fig. 12). By that time, a short-time phase of 


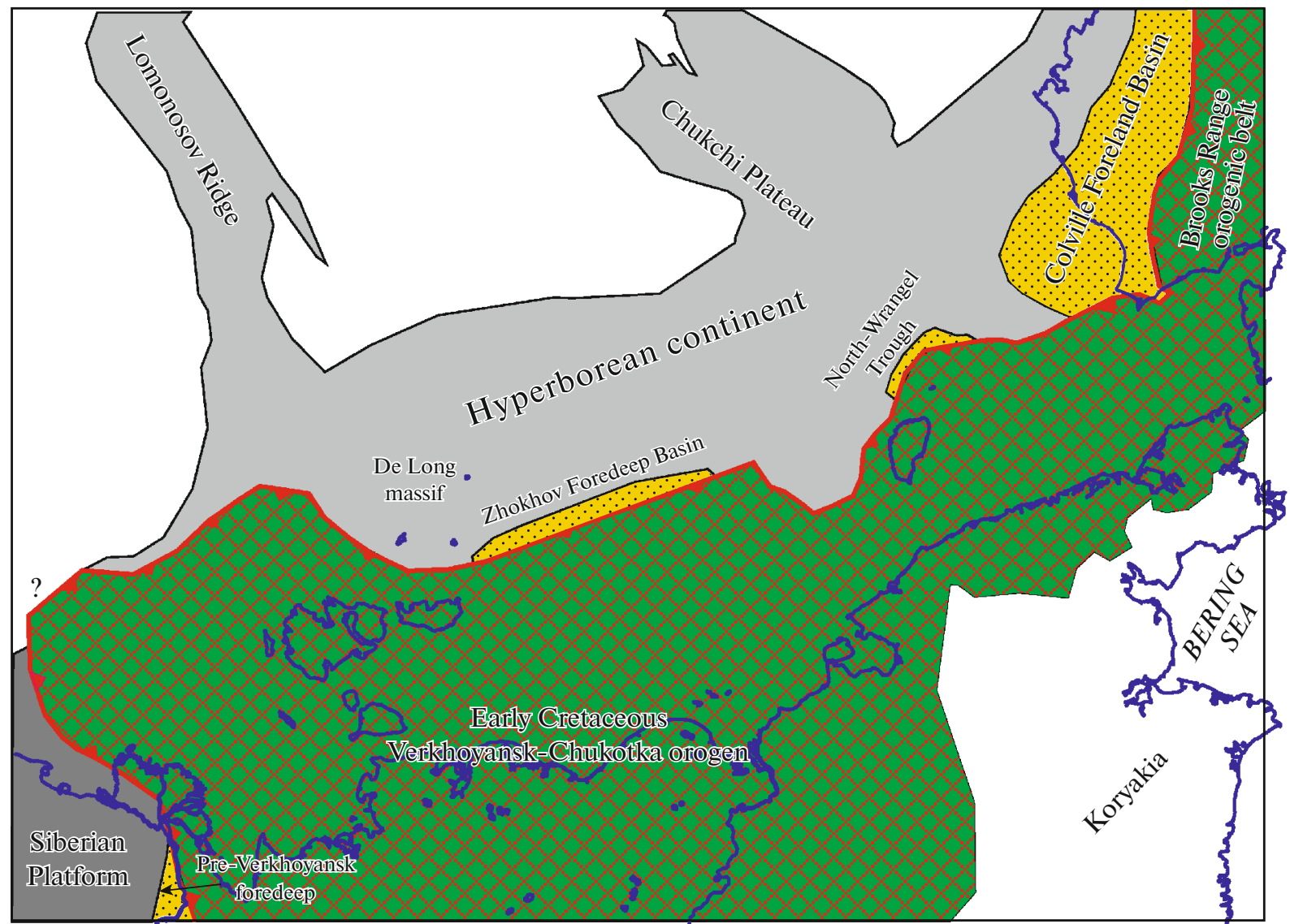

Fig. 17. Early Cretaceous, Neocomian (Berriasian-Barremian) main tectonic units on a modern geographical basis. Shown: Early Cretaceous thrust front (red line); Zhokhov and North-Wrangel foredeeps.

low-amplitude regional normal fault formation had occurred in the North-Chukchi Trough and in the troughs of the East Siberian Sea (Figs. 3, 9, 13). A phase of uplift and erosion at $\approx 45 \mathrm{Ma}$ is recorded along the southern margin of the North Chukchi Basin (Fig. 7). The time of formation of the Hope rift basin probably corresponds to the epoch of 45-34 Ma according to the data of its drilling [22]. A regional tectonic phase of extension or fault-extension (transtension) occurred in the shelf areas of the Chukchi and East Siberian Seas at approximately $45 \mathrm{Ma}$.

In the area of the East Siberian Sea in the Manskii and Melville Troughs are several possible rifting epochs. We cannot as yet correctly interpret the seismic data, but the possible phases of normal fault formation occurred at 125-100 Ma and in the Cenozoic, including the event at $\approx 45$ Ma (Figs. 9, 19). Syntectonic sequence-3 (34-20 Ma) is locally underlain by a chaotic horizon (Fig. 9) and the change in the geometry of the clinoform sequence is confined approximately to its base (Fig. 9). There are angular unconformities in the base and the roof of this sequence (Fig. 15). This sequence was likely to be formed against the background of compression strains. The Pegtymel Trough is an example of a Cretaceous rift with the main phase of compression and inversion at approximately 34-20 Ma (Fig. 15).

Towards the Lomonosov Ridge, a sequence with an age of 45-20 Ma decreases in thickness and perhaps wedges out. The phase of the relative uplift of the Lomonosov Ridge is likely to correspond to this time.

The sequence of the regional cover $(20-0 \mathrm{Ma})$ is characterized by smooth changes in thicknesses. The erosional boundaries, manifestations of gravity tectonics (landslides, channels, and erosion boundaries) are often confined to its base, which indicates that the regime of sea currents changed sharply in the Arctic Ocean at $\approx 20$ Ma.

\section{CONCLUSIONS}

In this work, we made the following conclusions:

(1) In the area of the Chukchi and East Siberian shelf seas and the adjacent deepwater basins, the main seismic mega-sequences or tectonostratigraphic units that we traced in the study region were identified with 


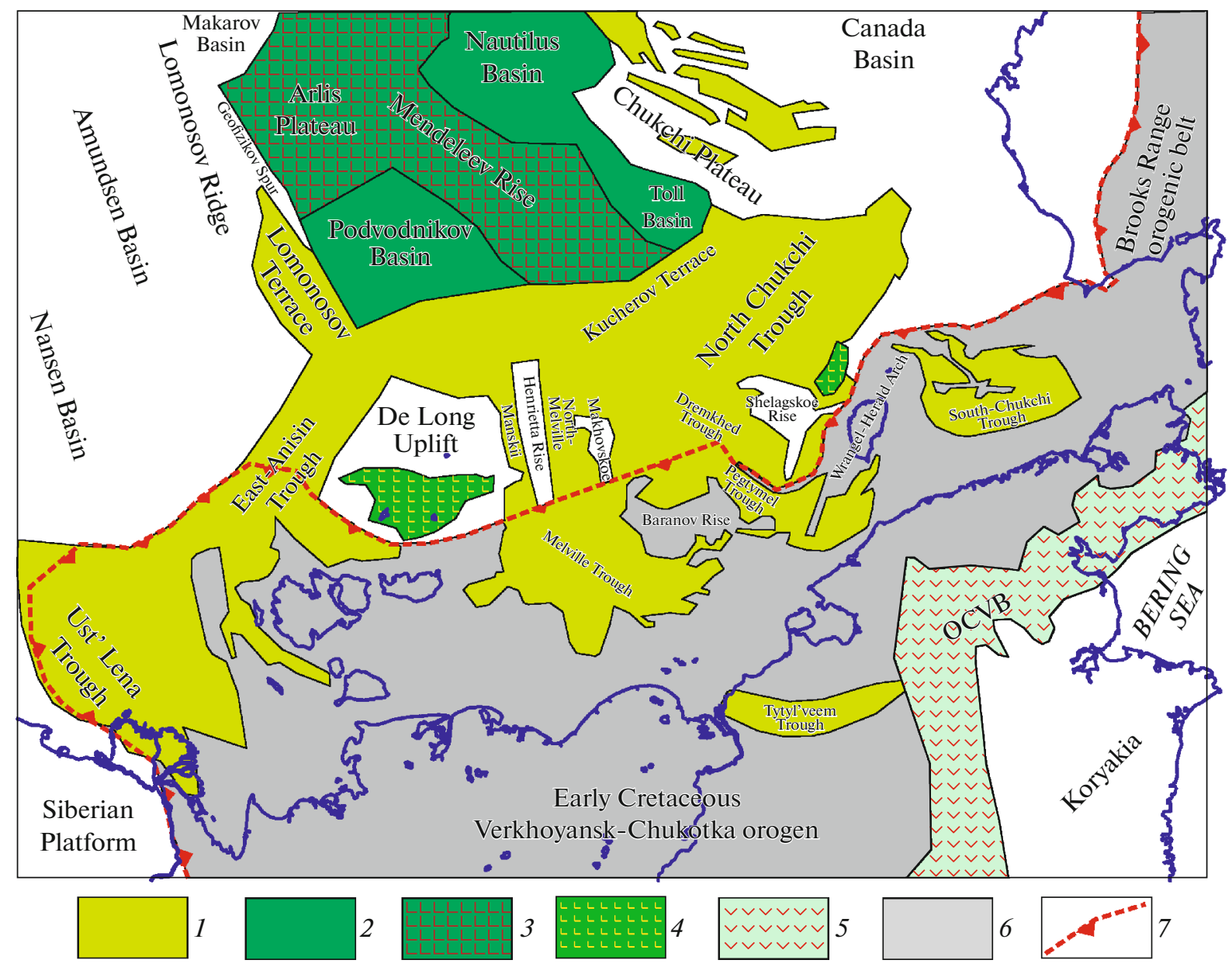

Fig. 18. Types of Aptian-Albian seismic sequences on a modern geographical basis. Arbitrary notes: $(1,2)$ synrift sequences on: (1) continental crust, (2) hyper-extended continental crust; (3) rift-volcanic sequences of the Mendeleev Rise; (4) probable basalt traps; (5) Cretaceous Okhotsk-Chukotka volcanic belt; (6) Cretaceous orogen areas; (7) position of the Pre-Aptian (Neocomian) front of thrusts.

conventional ages of $125-100,100-80,80-66$, 66-56, 46-45, 45-34, 34-20, and 20-0 Ma.

(2) We delineated the Pre-Aptian Zhokhov foredeep, which was formed between the VerkhoyanskChukotka orogen and the Hyperborean continent, between the New Siberian Islands and the De Long Islands. It is highly likely that the foredeep has a LateJurassic-Neocomian age and is synchronous in its time of formation with the Pre-Verkhoyansk foredeep:

In the Aptian-Albian (125-100 Ma) the main rifting phase occurred within the Chukchi and East Siberian Seas, as well as in the Podvodnikov and Toll Basins.

For the time interval of 100-66 Ma, a typical postrift subsidence with approximately uniform accumulation of a sedimentary cover has been revealed.

For the time interval of 66-20 Ma, a typical clinoform accumulation of sediments at the shelf edge has been recorded, in which case three syntectonic epochs of formation of clinoform sequences with ages of 66-45, 45-34, and 34-20 Ma have been identified.

The Mid-Brookian orogeny occurred in the area of Wrangel Island at approximately $66 \mathrm{Ma}$; this event is related to the phases of thrust formation, uplift and the onset of the formation of the clinoform sequence in the North-Chukchi Trough.

The rift phase with an age of 66-56 Ma has been identified for the slope of the Lomonosov Ridge.

The rift phase with an age of approximately $45 \mathrm{Ma}$, which was regionally manifested within the Chukchi and East Siberian Seas, has been recognized. During this rift phase, numerous grabens were formed, but the peculiarity of this rifting is related to the formation of the system of low-amplitude normal faults on the large territories.

A compression phase occurred between 34 and $20 \mathrm{Ma}$, in particular, the Pegtymel Trough underwent inversion. 


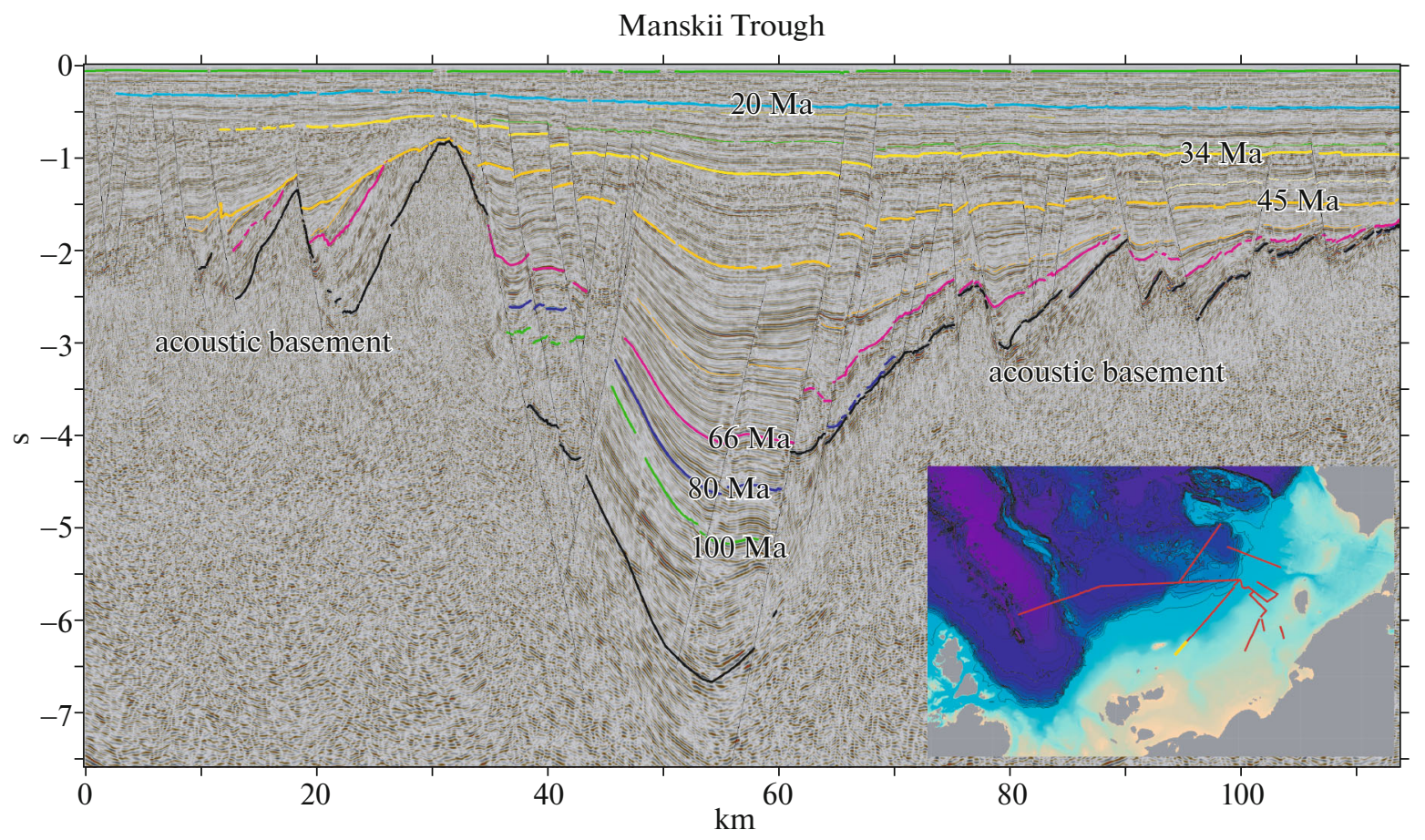

Fig. 19. Fragment composite seismic profile- 2 for the Manskii Trough area. Rift structure of the basin is shown.

In the interval of 20-0 Ma a relatively uniform tectonic setting with approximately equal thicknesses of the sedimentary cover occurred.

\section{ACKNOWLEDGMENTS}

We are grateful to personnel of PAO Rosneft' E.A. Bulgakova, A.B. Popova, I.V. Mazaeva, O.S. Makhova, M.V. Skaryatin, A.A. Borodulin, B.I. Ikhsanov, and others for the discussion of our materials. The multiple debates with the colleagues from Moscow, St. Petersburg, and Novosibirsk contributed to even deeper discussion of the problems considered in this work. We appreciate OAO Marine Arctic Geological Expedition (MAGE, Murmansk, Russia), OAO Sevmorneftegeofizika (SMNG Murmansk, Russia), OAO Dal'morneftegeofizika (YuzhnoSakhalinsk, Russia) for providing the opportunity to use seismic data.

\section{FUNDING}

This work was supported by the Russian Foundation for Basic Research, grant nos. 18-05-70011 and 18-05-00495.

\section{OPEN ACCESS}

This article is distributed under the terms of the Creative Commons Attribution 4. International license (http://creativecommons.org/licenses/by/4.0/), which permits unrestricted use, distribution, and reproduction in any medium, provided you give appropriate credit to the original author(s) and the source, provide a link to the Creative Commons license, and indicate if changes were made.

\section{REFERENCES}

1. N. A. Bogdanov, Tectonic Evolution of the Kolyma Massif and East Arctic in the Paleozoic, Vol. 99A of Tr. Geol. Inst. Akad. Nauk SSSR, Ed. by A. V. Peive and Yu. M. Pushcharovskii (Nauka, Moscow, 1963).

2. V. A. Vernikovsky, N. L. Dobretsov, D. V. Metelkin, N. Yu Matushkin, and I. Yu. Koulakov, "Concerning tectonics and the tectonic evolution of the Arctic," Russ. Geol. Geophys. 54, 838-858 (2013).

3. B. I. Ikhsanov, Candidate's Dissertation in Geology and Mineralogy (Moscow, 2014).

4. G. S. Kazanin, Yu. B. Barabanova, T. A. KirillovaPokrovskaya, S. F. Chernikov, S. P. Pavlov, and G. I. Ivanov, "Continental margin of the East Siberia Sea: Geological structure and petroleum-bearing potential," Razved. Okhrana Nedr, No. 10, 51-55 (2017).

5. G. S. Kazanin, V. A. Poselov, I. V. Zayats, G. I. Ivanov, E. S. Makarov, A. S. Vasil'ev, and O. E. Smirnov, "Comprehensive geophysical studies in the area of central deep-water part of the Arctic Ocean," Razved. Okhrana Nedr, No. 10, 25-30 (2017).

6. A. M. Nikishin, E. I. Petrov, K. Gaina, N. A. Malyshev, and S. I. Freiman, "Tectonic reconstructions of the Arctic region for the Late Jurassic-Cenozoic time," in Problems of Tectonics of Continents and Oceans: Proceedings of the LI Meeting on Tectonics (GEOS, Moscow, 2019), Vol. 2, pp. 83-86. 
7. N. A. Petrovskaya and M. A. Savishkina, "Comparison between seismic complexes and main unconformities in the sedimentary cover of the East Arctic," Neftegaz. Geol. Teor. Prakt. 9 (3), 1-26 (2014).

8. A. B. Popova, O. S. Makhova, N. A. Malyshev, V. E. Verzhbitskii, V. V. Obmetko, and A. A. Borodulin, "Construction of a complex seismogeological model of the East Siberia Sea shelf," Neft. Khoz., No. 4, 30-34 (2018).

9. V. A. Poselov, G. P. Avetisov, V. V. Butsenko, S. M. Zholondz, V. D. Kaminskii, and S. P. Pavlov, "The Lomonosov Ridge as a natural extension of the Eurasian continental margin into the Arctic Basin," Russ. Geol. Geophys. 53, 1276-1290 (2012).

10. Yu. M. Pushcharovskii, "Some general problems of tectonics of the Arctic," Izv. Akad. Nauk SSSR. Ser. Geol., No. 9, 15-28 (1960).

11. S. I. Freiman, A. M. Nikishin, and E. I. Petrov, "Cenozoic clinoform complexes and geological evolution of the North Chukchi Basin,” Moscow Univ. Geol. Bull. (2019) (in press).

12. A. A. Chernykh and A. A. Krylov, "Sedimentogenesis in the Amundsen Basin from geophysical data and drilling results on the Lomonosov Ridge," Dokl. Earth Sci. 440, 1372-1376 (2011).

13. N. S. Shatskii, "Tectonics of the Arctic region," in $\mathrm{Ge}-$ ology and Mineral Resources of the North of the USSR, Ed. by A. D. Arkhangel'skii (Glavsevmorput', Leningrad, 1935), pp. 149-165.

14. E. V. Shipilov, "Basaltic magmatism and strike-slip tectonics in the Arctic margin of Eurasia: Evidence for the early stage of geodynamic evolution of the Amerasia Basin,” Russ. Geol. Geophys. 57, 1668-1687 (2016).

15. M. M. Abdelmalak, R. Meyer, S. Planke, J. I. Faleide, L. Gernigon, J. Frieling, A. Sluijs, G.-J. Reichart, D. Zastrozhnov, S. Theissen-Krah, A. Said, and R. Myklebust, "Pre-breakup magmatism on the Vøring Margin: Insight from new sub-basalt imaging and results from Ocean Drilling Program Hole 642E," Tectonophysics 675, 258-274 (2016).

16. J. M. Amato, J. Toro, V. V. Akinin, B. A. Hampton, A. S. Salnikov, and M. I. Tuchkova, "Tectonic evolution of the Mesozoic South Anyui suture zone, eastern Russia: A critical component of paleogeographic reconstructions of the Arctic region," Geosphere 11 (2015). https://doi.org/10.1130/GES01165.1

17. J. Backman, M. Jakobsson, M. Frank, F. Sangiorgi, H. Brinkhuis, C. Stickley, M. O'Regan, R. Løvlie, H. Pälike, D. Spofforth, J. Gattacecca, K. Moran, J. King, and C. Heil, "Age model and core-seismic integration for the Cenozoic Arctic Coring Expedition sediments from the Lomonosov Ridge," Paleoceanography 23, 1-15 (2008).

18. K. Brumley, PhD Thesis (Stanford, Calif., 2014).

19. V. Bruvoll, Y. Kristoffersen, B. J. Coakley, and J. R. Hopper, "Hemipelagic deposits on the Mendeleev and northwestern Alpha submarine Ridges in the Arctic Ocean: Acoustic stratigraphy, depositional envi- ronment and an inter-ridge correlation calibrated by the ACEX results," Mar. Geophys. Res. 31, 149-171 (2010).

20. V. Bruvoll, Y. Kristoffersen, B. J. Coakley, J. R. Hopper, S. Planke, and A. Kandilarov, "The nature of the acoustic basement on Mendeleev and northwestern Alpha ridges, Arctic Ocean," Tectonophysics 514-517, 123-145 (2012).

21. B. Coakley, K. Brumley, N. Lebedeva-Ivanova, and D. Mosher, "Exploring the geology of the central Arctic Ocean; understanding the basin features in place and time," J. Geol. Soc. (London, U. K.) 173, 967-987 (2016).

22. W. H. Craddock, T. E. Moore, P. B. O'Sullivan, C. J. Potter, and D. W. Houseknecht, "Late CretaceousCenozoic exhumation of the western Brooks Range, Alaska, revealed from apatite and zircon fission track data," Tectonics 37, 4714-4751 (2018).

23. L. A. Daragan-Sushchova, O. V. Petrov, N. N. Sobolev, Yu. I. Daragan-Sushchov, L. R. Grin'ko, and N. A. Petrovskaya, "Geology and tectonics of the Northeast Russian Arctic region, based on seismic data," Geotectonics 49, 469-484 (2015).

24. S. Drachev, N. Malyshev, and A. Nikishin, "Tectonic history and petroleum geology of the Russian Arctic Shelves: An overview," in Petroleum Geology: From Mature Basins to New Frontiers, Vol. 7 of Geol. Soc. London, Pet. Geol. Conf. Ser., Ed. by B. A. Vining and S. C. Pickering (Geol. Soc. London, London, 2010), pp. 591-619. https://doi.org/10.1144/0070591

25. S. S. Drachev, S. Mazur, S. Campbell, C. Green, and A. Tishchenko, "Crustal architecture of the East Siberian Arctic Shelf and adjacent Arctic Ocean constrained by seismic data and gravity modeling results," J. Geodyn. 119, 123-148 (2018).

26. J. Evangelatos and D. C. Mosher, "Seismic stratigraphy, structure and morphology of Makarov Basin and surrounding regions: tectonic implications," Mar. Geol. 374, 1-13 (2016).

27. C. Gaina, A. M. Nikishin, and E. I. Petrov, "Ultraslow spreading, ridge relocation and compressional events in the East Arctic region: A link to the Eurekan orogeny?," Arktos 1 (2015). https://doi.org/10.1007/s41063-015-0006-8

28. L. Geoffroy, "Volcanic passive margins," C. R. Geosci. 337, 1395-1408 (2005).

29. A. Hegewald and W. Jokat, "Tectonic and sedimentary structures in the northern Chukchi region, Arctic Ocean,” J. Geophys. Res.: Solid Earth 118, 3285-3296 (2013).

30. D. W. Houseknecht and K. J. Bird, "Geology and petroleum potential of the rifted margins of the Canada basin," in Arctic Petroleum Geology, Vol. 35 of Geol. Soc. London, Mem., Ed. by A. Spencer, A. F. Embry, D. L. Gautier, A. V. Stoupakova, and K. Sørensen (London, 2011), pp. 509-526.

31. D. W. Houseknecht, K. J. Bird, and C. J. Schenk, "Seismic analysis of clinoform depositional sequences and shelf-margin trajectories in Lower Cretaceous (Al- 
bian) strata, Alaska North Slope," Basin Res. 21, 644654 (2009).

32. I. Ilhan and B. J. Coakley, "Meso-Cenozoic evolution of the Chukchi Shelf and North Chukchi Basin, Arctic Ocean," Mar. Petrol. Geol. 95, 100-109 (2018).

33. M. Jakobsson, J. Backman, B. Rudels, J. Nycander, L. Mayer, F. Sangiorgi, H. Brinkhuis, M. O’Regan, W. Jokat, M. Frank, J. King, and K. Morane, "The Early Miocene onset of a ventilated circulation regime in the Arctic Ocean," Nature 447, 987-990 (2007).

34. W. Jokat, M. Ickrath, and J. O’Connor, "Seismic transect across the Lomonosov and Mendeleev Ridges: Constraints on the geological evolution of the Amerasia Basin, Arctic Ocean," Geophys. Res. Lett. 40, 1-5 (2013).

35. W. Jokat and M. Ickrath, "Structure of ridges and basins off East Siberia along $81^{\circ} \mathrm{N}$, Arctic Ocean," Mar. Petrol. Geol. 64, 222-232 (2015).

36. S. N. Kashubin, O. V. Petrov, I. M. Artemieva, A. F. Morozov, D. V. Vyatkina, Yu. S. Golysheva, T. V. Kashubina, E. D. Milshtein, A. V. Rybalka, Yu. M. Erinchek, T. S. Sakulina, N. A. Krupnova, and A. A. Shulgin, "Crustal structure of the Mendeleev Rise and the Chukchi Plateau (Arctic Ocean) along the Russian wide-angle and multichannel seismic reflection experiment 'Arctic-2012',' J. Geodyn. 119, 107122 (2018).

37. M. A. Khoroshilova, D. Franke, T. Kirillova, B. Mouly, and A. M. Nikishin, "Dating and correlation of reference seismic horizons in the Laptev Sea Basin," Moscow Univ. Geol. Bull. 69, 271-280 (2014).

38. N. Kumar, J. W. Granath, P. A. Emmet, J. A. Helwig, and M. G. Dinkelman, "Stratigraphic and tectonic framework of the US Chukchi Shelf: Exploration insights from a new regional deep-seismic reflection survey," in Arctic Petroleum Geology, Vol. 35 of Geol. Soc. London, Mem., Ed. by A. Spencer, A. F. Embry, D. L. Gautier, A. V. Stoupakova, and K. Sørensen (London, 2011), pp. 501-508.

39. A. B. Kuzmichev, "Where does the South Anyui suture go in the New Siberian islands and Laptev Sea? Implications for the Amerasia basin origin," Tectonophysics 463, 86-108 (2009).

40. N. P. Laverov, L. I. Lobkovsky, M. V. Kononov, N. L. Dobretsov, V. A. Vernikovsky, S. D. Sokolov, and E. V. Shipilov, "A geodynamic model of the evolution of the Arctic basin and adjacent territories in the Mesozoic and Cenozoic and the outer limit of the Russian Continental Shelf," Geotectonics 47, 1-30 (2013).

41. N. Lebedeva-Ivanova, C. Gaina, A. Minakov, and S. Kashubin, "ArcCRUST: Arctic crustal thickness from 3-D gravity inversion," Geochem., Geophys., Geosyst. 7 (2019). https://doi.org/10.1029/2018GC008098

42. M. D. Lineva, N. A. Malyshev, and A. M. Nikishin "The structure and seismostratigraphy of the sedimentary basins of the East Siberian Sea," Moscow Univ. Geol. Bull. 70, 1-7 (2015).
43. E. Miller and V. Verzhbitsky, "Structural studies near Pevek, Russia: Implications for formation of the East Siberian Shelf and Makarov Basin of the Arctic Ocean," in Geology and Tectonic Origins of Northeast Russia: A Tribute to Leonid Parfenov, Vol. 4 of Stephan Mueller Spec. Publ. Ser., Ed. by D. B. Stone, K. Fujita, P. W. Layer, E. L. Miller, A. V. Prokopiev, and J. Toro (2009), pp. 223-241.

44. Mineral Management Service, Chukchi Sea Planning Area (Alaska) - Province Summary, 2006 Oil and Gas Assessment. https://www.boem.gov/uploadedFiles/ BOEM/About_BOEM/BOEM_Regions/Alaska_Region/Resource_Evaluation/2006-Assessment-Files/ Chukchi\%20Sea\%20Province\%20Summary-2006\%20 Assessment.pdf. Accessed September 15, 2019.

45. T. E. Moore, P. B. O'Sullivan, C. J. Potter, and R. A. Donelick, "Provenance and detrital zircon geochronologic evolution of lower Brookian foreland basin deposits of the western Brooks Range, Alaska, and implications for early Brookian tectonism," Geosphere 11, 93-122 (2015).

46. A. M. Nikishin and L. F. Kopaevich, "Tectonostratigraphy as a basis for paleotectonic reconstructions," Moscow Univ. Geol. Bull. 64, 65-74 (2009).

47. A. M. Nikishin, N. A. Malyshev, and E. I. Petrov, Geological Structure and History of the Arctic Ocean (EAGE, Houten, the Netherlands, 2014).

48. A. M. Nikishin, C. Gaina, E. I. Petrov, N. A. Malyshev, and S. I. Freiman, "Eurasia Basin and Gakkel Ridge, Arctic Ocean: Crustal asymmetry, ultraslow spreading and continental rifting revealed by new seismic data," Tectonophysics 746, 64-82 (2018).

49. A. M. Nikishin, E. I. Petrov, N. A. Malyshev, and V. P. Ershova, "Rift systems of the Russian Eastern Arctic shelf and Arctic deep water basins: Link between geological history and geodynamics," Geodin. Tectonofiz. 8 (1), 11-43 (2017).

50. L. M. Parfenov and B. A. Natal'in, "Mesozoic tectonic evolution of Northeastern Asia," Tectonophysics 127, 291-304 (1986).

51. V. Pease, S. Drachev, R. Stephenson, and X. Zhang, "Arctic lithosphere - A review," Tectonophysics 628, $1-25$ (2014).

52. G. Peron-Pinvidic and P. T. Osmundsen, "The Mid Norwegian - NE Greenland conjugate margins: Rifting evolution, margin segmentation, and breakup," Mar. Pet. Geol. 98, 162-184 (2018).

53. O. Petrov, A. Morozov, S. Shokalsky, S. Kashubin, I. M. Artemieva, N. Sobolev, E. Petrov, R. E. Ernst, S. Sergeev, and M. Smelror, "Crustal structure and tectonic model of the Arctic region," Earth-Sci. Rev. 154. P.29-71 (2016).

54. A. Piskarev, V. Poselov, and V. Kaminsky, Geologic Structures of the Arctic Basin (Springer, New York, 2019). https://doi.org/10.1007/978-3-319-77742-9

55. S. B. Sekretov, "Northwestern margin of the East Siberian Sea, Russian Arctic: Seismic stratigraphy, structure of the sedimentary cover and some remarks on the tectonic history," Tectonophysics 339, 353-383 (2001). 
56. K. W. Sherwood, P. P. Johnson, J. D. Craig, S. A. Zerwick, R. T. Lothamer, D. K. Thurston, and S. B. Hurlbert, "Structure and stratigraphy of the Hanna Trough, U.S. Chukchi Shelf, Alaska," in Tectonic Evolution of the Bering Shelf-Chukchi Sea-Arctic Margin and Adjacent Landmasses, Vol. 360 of Geol. Soc. Am., Spec. Pap., Ed. by E. L. Miller, A. Grantz, and S. L. Klemperer (Geol. Soc. Am., Boulder, Colo., 2002), pp. 39-66.

57. S. Skolotnev, G. Akeksandrova, T. Isakova, T. Tolmacheva, A. Kurilinko, E. Raevskaya, E. Rozhnov, E. Petrov, and A. Korniychuk, "Fossils from seabed bedrocks: Implication to the nature of the acoustic basement of the Mendeleev Rise (the Arctic Ocean)," Mar. Pet. Geol. 407, 148-163 (2019).

58. S. D. Sokolov, "Tectonics of Northeast Asia: An overview," Geotectonics 44, 493-509 (2010).

59. R. Stein, Arctic Ocean Sediments: Processes, Proxies, and Paleoenvironment (Elsevier, New York, 2008), Vol. 2.

60. R. Stein, W. Jokat, F. Niessen, and E. Weigelt, "Exploring the long-term Cenozoic Arctic Ocean climate history - A challenge within the International Ocean Discovery Program (IODP)," Arktos 1 (2015). https://doi.org/10.1007/s41063-015-0012-X

61. A. V. Stoupakova, E. Henriksen, Yu. K. Burlin, G. B. Larsen, J. K. Milne, T. A. Kiryukhina, P. O. Golynchik, S. I. Bordunov, M. P. Ogarkova, and A. A. Suslova, "The geological evolution and hydrocarbon potential of the Barents and Kara shelves," in Arctic
Petroleum Geology, Vol. 35 of Geol. Soc. London, Mem., Ed. by A. Spencer, A. F. Embry, D. L. Gautier, A. V. Stoupakova, and K. Sørensen (London, 2011), pp. $325-344$.

62. V. E. Verzhbitsky, S. D. Sokolov, M. I. Tuchkova, E. M. Frantzen, A. Little, and L. I. Lobkovsky, "The South Chukchi sedimentary basin (Chukchi Sea, Russian Arctic): Age, structural pattern, and hydrocarbon potential," in Tectonics and Sedimentation: Implications for Petroleum Systems, Vol. 100 of AAPG Mem., Ed. by D. Gao (2012), pp. 267-290.

63. E. Weigelt, D. Franke, and W. Jokat, "Seismostratigraphy of the Siberian Arctic Ocean and adjacent Laptev Sea Shelf," J. Geophys. Res.: Solid Earth 119, 5275-5289 (2014).

64. M.-C. Williamson, D. Kellett, D. Miggins, A. Koppers, G. Oakey, D. Weis, W. Jokat, E. Massey, and R. Carey, "Age and eruptive style of volcanic rocks dredged from the Alpha Ridge, Arctic Ocean," Geophys. Res. Abstr. 21, Abstr. No. EGU2019-6336 (2019).

65. Geology of the USSR: A Plate Tectonic Synthesis, Vol. 21 of Am. Geophys. Union, Geodyn. Ser., Ed. by L. P. Zonenshain, M. I. Kuzmin, L. M. Natapov, and B. M. Page (Am. Geophys. Union, 1990).

https://doi.org/10.1029/GD021

Translated by L. Mukhortova 